\title{
Cliff Recession and Progressive Development of Talus Deposits around Xiangshan of the Taipei Sishou Hills
}

\author{
Chia-Ming Lo ${ }^{1}$, Ming-Lang Lin ${ }^{1, *}$, Wei-Chu Lee ${ }^{1}$, Yu-Chang Chan ${ }^{2}$, and Chih-Hsiang Yeh ${ }^{1}$ \\ ${ }^{1}$ Department of Civil Engineering, National Taiwan University, Taipei, Taiwan, ROC \\ ${ }^{2}$ Institute of Earth Sciences, Academia Sinica, Taipei, Taiwan, ROC
}

Received 30 April 2008, accepted 26 October 2009

\begin{abstract}
This paper presents results of a case study on cliff recession mechanism and progressive development of talus deposits around Xiangshan of the Sishou Hills in the southeast of the Taipei Basin. Based on photogrammetric analysis and physical modeling, the geomorphologic changes of talus deposits are carefully examined and the cliff recession rates from 1904 to 2005 are thus measured and tabulated. Our study identified the fundamental control factors on mechanisms of cliff recession and proposed a possible scenario of cliff recession and progressive development of talus deposits around the Xiangshan region from 1904 to 2005.
\end{abstract}

Key words: Cliff recession, Talus deposits, Physical model, Xiangshan

Citation: Lo, C. M., M. L. Lin, W. C. Lee, Y. C. Chan, and C. H. Yeh, 2010: Cliff recession and progressive development of talus deposits around Xiangshan of the Taipei Sishou Hills. Terr. Atmos. Ocean. Sci., 21, 543-561, doi: 10.3319/TAO.2009.10.26.01(TH)

\section{INTRODUCTION}

The Taipei Basin in northern Taiwan is geologically young and unstable. During storms or earthquakes, rockfall is a frequent mishap in mountain areas. Xiangshan, or Elephant Mountain in Chinese, with elevation of $183 \mathrm{~m}$ is located west of Nangangshan (elevation $360 \mathrm{~m}$ ), on the eastern edge of the Taipei Basin (Fig. 1). The eastern cliff of Xiangshan is a cataclinal slope, whereas the western cliff is an anaclinal slope. Geologic strata exposed on the cliff face of Xiangshan comprise the Shihti Formation in the upper cliff and the Taliao Formation in the lower. The lower part of the Shihti Formation is composed of massive white sandstone with several sets of joints which often forms precipitous scarps and constitutes a good lithologic key bed; whereas the upper part of the Taliao Formation is mainly made up of interbeds of sandstone and shale (Fig. 1). The eastern cliff line has retreated by up to $50 \mathrm{~m}$ between 1904 and 2005 . Several talus fan deposits with rock blocks of 1 to $15 \mathrm{~m}$ in size lie on the toes of the slope below the cliffs. Temples and houses located nearby are under the threat of rockfall.

Talus deposits are the unique result of an accumulation

\footnotetext{
* Corresponding author

E-mail:mlin@ccms.ntu.edu.tw
}

of large amounts of detached rock blocks from cliff faces; and, their features vary in keeping with differences in cliff recession patterns. A series of studies and field investigations on topographic features of existing cliffs were undertaken to facilitate further assessment of cliff retreat rates and progressive development of talus deposits. Many studies have focused on the relationship between talus development and rockwall retreat (Hinchliffe and Ballantyne 1999; Curry and Morris 2004; Pierre 2006; Pierre and Lahousse 2006). In this study we followed the general practice in photogrammetric analysis for cliff retreat rates (Pierre 2006; Pierre and Lahousse 2006). However, long-term exposure to in-situ disturbances has since obscured the features of talus deposits rendering it quite impossible to identify accurate deposition evolution from photogrammetric analyses and field surveys.

Understanding the talus development process is important in talus investigation (Hutchinson et al. 2001; Santos et al. 2004; Obanawa and Matsukura 2006; Andriani and Walsh 2007; Drake and Phipps 2007). Among recent studies undertaken to investigate the behavior and mechanism of cliff recession, Obanawa and Matsukura (2008) proposed mathematical relations for evaluating historical changes in cliff recession and talus deposition features over time. Their 


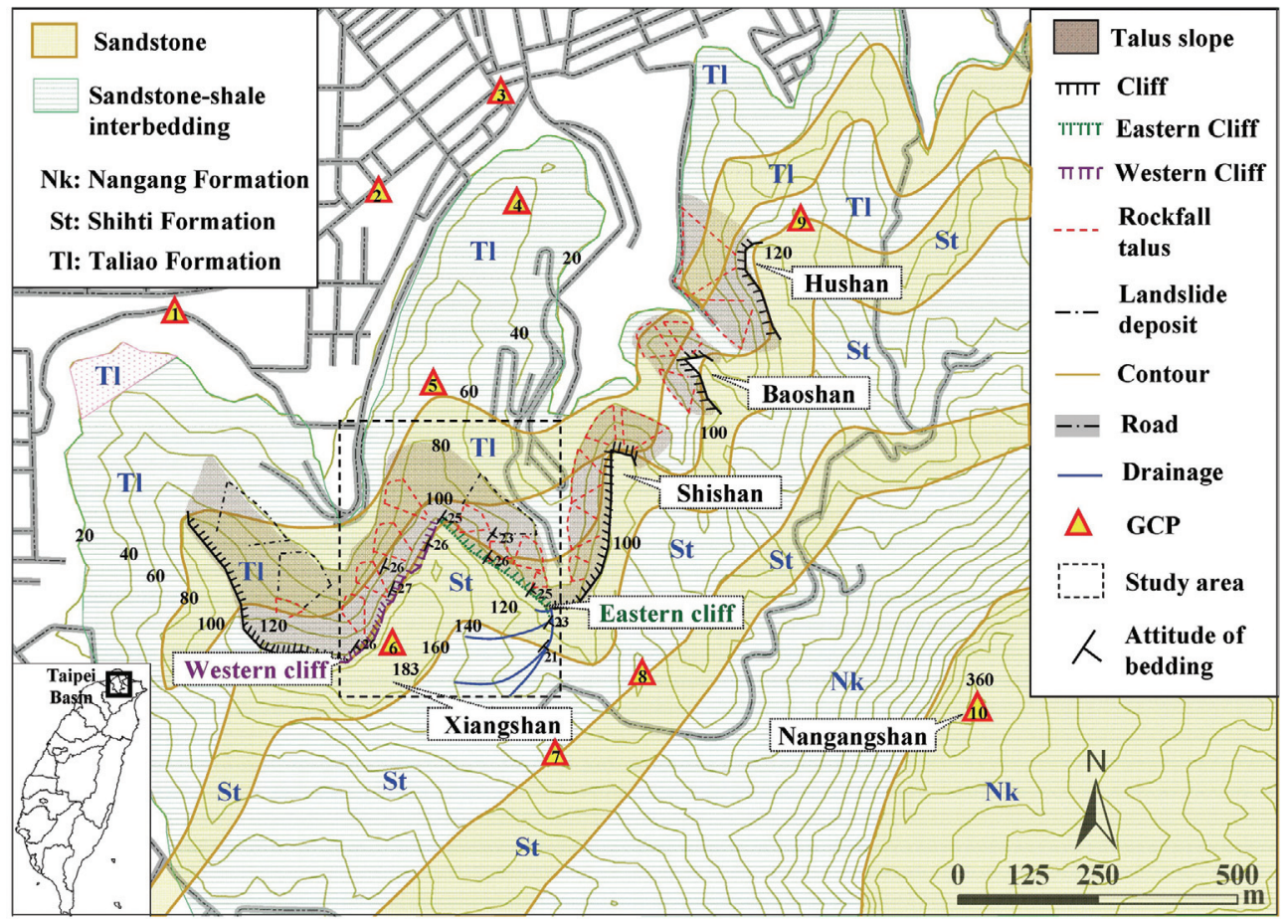

Fig. 1. Topographic map showing the location of Xiangshan (Elephant Mountain), Taipei.

case study on the caldera wall of Mount St. Helens was presented to verify the application. Prior to Obanawa and Matsukura's proposal there were sparse analyses of the relationship between cliff recession and talus deposition patterns with a focus on mechanism together with the influence of rockwall retreat.

In this study we aim to: (a) assess the recession rate and mechanism of both eastern and western cliffs in Xiangshan; (b) establish the relationship between cliff recession and the talus deposition features. We analyzed the geomorphologic changes of cliffs and talus deposits in Xiangshan based on the findings from the topographic maps at five periods $(1904,1936,1988,1996$, and 2005) and aerial photos at two periods (1962 and 2005). Field investigations were conducted to assess the recession mechanism. Controlled laboratory model tests were carried out to measure the amount of rockfall and basal surface beneath the talus sediment in order to verify simplified deposition patterns.

\section{METHODOLOGY}

The research methods adopted in this investigation are shown in Fig. 2. They included field investigation, analysis of topographic maps and aerial photos, and physical modelings. Field investigation, field survey of outcrops, and tension cracks recording on the cliffs and locations of talus deposits and groundwater seepage, provided the basic geological information. A geomorphic analysis via topographic map and aerial photo interpretation revealed changes of cliff lines and deposition features at different periods. Laboratory physical modeling tests carried out by simplifying insitu rockfall behavior allowed an insight into the influential factors of cliff recession and the relationship with talus deposition patterns. Finally, the present Xiangshan case study provided a basis for discussion on the influential factors which include the rockfall mechanism, original topographic slope, rock joint distribution, rockfall amount, and rockfall processes.

\section{FIELD INVESTIGATION}

Field investigation work covered rock outcrops on the western and eastern cliffs in Xiangshan. Field survey work consisted of mainly measuring the dip direction and dip angle of rock beddings and joints. The measurement locations were recorded by the Global Position System (GPS). The measurement data, the internal consistency from the concentration of correlation of which was estimated, were entered into statistical software (Dip 5.1; Rocscience 2002) for further analysis. With reference to phenomenon observed from field investigation, different cliff recession mechanisms in various topography and geology were investigated and scrutinized.

\section{GEOMORPHIC ANALYSIS}

The features of topography and geomorphology are useful clues in the assessment of historic changes of cliff 


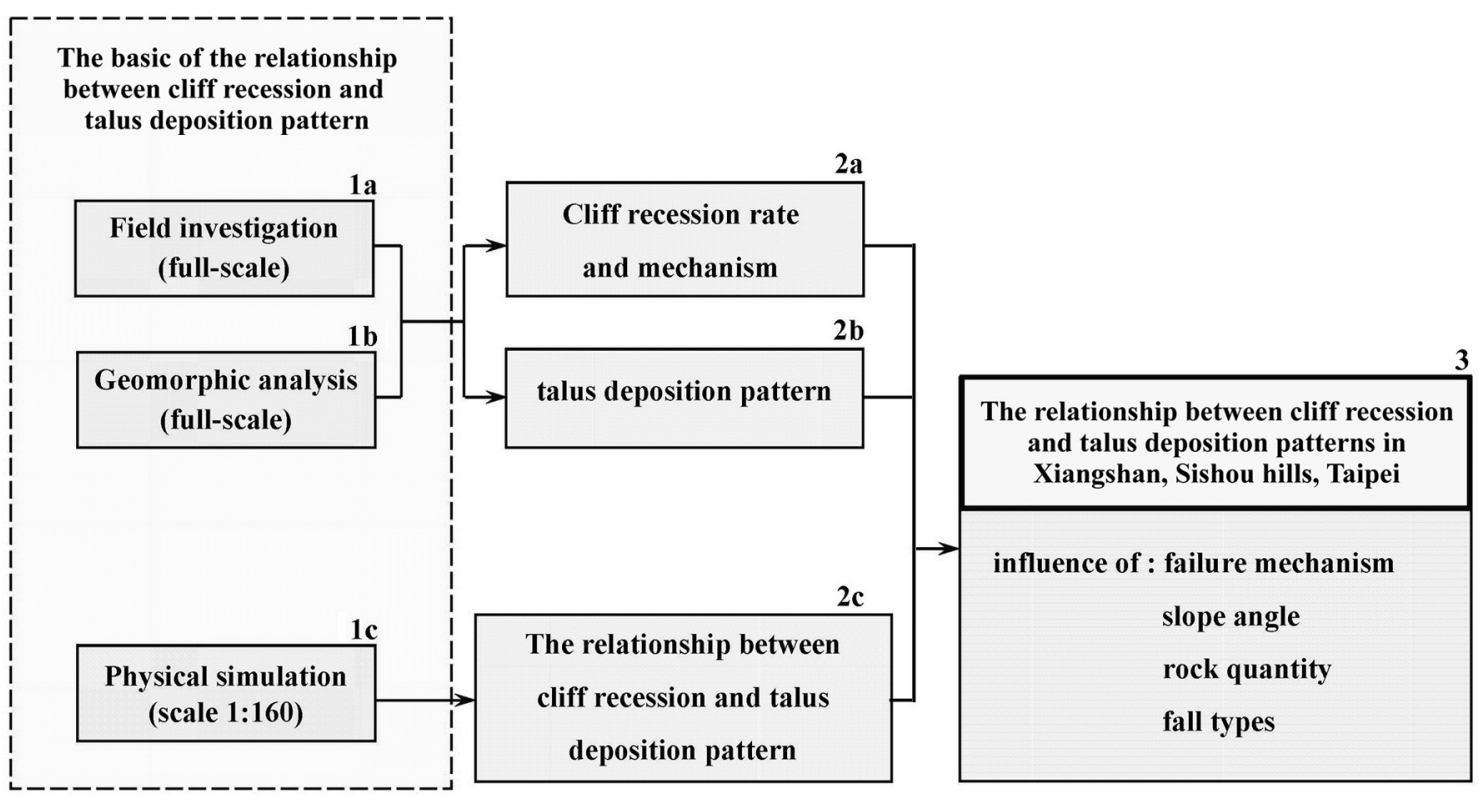

Fig. 2. Flow chart showing our step-by-step research method.

recession and development of talus deposits. The contours of topographic map analysis provide important information on the size, shape, and depiction of a landslide area. In this paper, the orthographic topographic maps, at scales of 1 : $5000,1: 25000$, and $1: 50000$ released in $1904,1936,1988$, and 1996, were used to analyze the changes of cliff line and geomorphic features.

Aerial photographs can provide valuable information about spatial conditions affecting slope stability in landslide areas. For example, cliff features such as scarps and fissures can be accentuated by low-angle illumination. The tone, texture, pattern, shape, and lineament gleaned from aerial photos reflect ground conditions or landforms associated with slope stability. In this paper, aerial photographs, taken at scales of $1: 5000$ in 1962 and 2005, were used to investigate the cliff line features and talus deposition features.

The geographical information system database (ArcView GIS) was used to perform the calibration of coordinates of the image data. After the completion of coordinate the calibration via ten ground control reference points (GCP; Table 1 and Fig. 1), a overlay analysis was carried out to evaluate the RMS errors of image data (Table 2). The coordinates of the ten GCPs chosen from the 1996 orthophotographic base map at scales of $1: 5000$ measured with GPS in the field are assumed to be accurate values. The coordinates and coordinate errors of these intersection points at each period were interpolated from the coordinates and coordinate errors from those of the three nearest GCPs at that time. The recession distance is calculated from the coordinate changes of the intersection points in between the two maps. Also, the recession distance errors are calculated from the sum of coordinates errors of the intersection points in between the two maps. The RMS error of the topographic map in 1904 was restrained roughly at $5 \mathrm{~m}$, which indicated that a cliff recession distance of more than $5 \mathrm{~m}$ would be more reliable.

In the same way, the RMS errors of other image data were restrained to within $1.5-2 \mathrm{~m}$ which indicated that it would be more reliable for a cliff recession distance greater than $2 \mathrm{~m}$. Airborne LiDAR (Light Detection and Ranging) data was then processed to reveal a high spatial and vertical resolution Digital Surface Model (DSM). The DSM represents an elevation model that includes human construction, vegetation, and reflects part of the true ground surface (Chan et al. 2007). This research interpreted the lineation of top cliff through LiDAR DSM. A chronological overlay of aerial photographs with high resolution LiDAR DSM was carried out at 2005 - 2006 and interprets the joints, cliff lines, and talus deposition areas below the cliffs. The LiDAR DSM acquired in 2006, $1 \mathrm{~m}$ resolution for this study, was provided by the Taiwan Central Geological Survey. Finally, eight profile lines roughly perpendicular to the cliffs passing through the central part of talus fans in Xiangshan were set to record the location and height of the cliff line and deposition patterns at different periods. Accordingly, the recession rate $\left(\mathrm{m} \mathrm{yr}^{-1}\right)$ was calculated in the study area during a specific period of time.

\section{PHYSICAL MODELING}

The features of present talus deposits differ drastically from the original ones owing to prolonged exposure to artificial and natural disturbances. The physical modeling is a useful method to provide more information towards explor- 
Table 1. Listing of coordinates for 10 ground control points.

\begin{tabular}{ccc}
\hline \multirow{2}{*}{$\begin{array}{c}\text { Ground control } \\
\text { point No. }\end{array}$} & \multicolumn{2}{c}{ GCP coordinate (TM-II-67) } \\
\cline { 2 - 3 } 1 & $\mathbf{E}$ & $\mathbf{N}$ \\
\hline 2 & 306916.50 & 2769702.83 \\
3 & 307275.34 & 2769925.97 \\
4 & 307490.97 & 2770104.05 \\
5 & 307571.07 & 2769928.83 \\
6 & 307380.83 & 2769525.47 \\
7 & 307250.33 & 2769043.57 \\
8 & 307611.12 & 2768907.55 \\
9 & 307765.59 & 2769039.14 \\
10 & 308107.93 & 2769975.08 \\
\hline & 308332.97 & \\
\hline
\end{tabular}

Table 2. Listing of map types, year published, scale, and RMS errors.

\begin{tabular}{lccc}
\hline Map type & Time & Scale & RMS (m) \\
\hline Topographic map & 1904 & $1: 20000$ & 4.27 \\
& 1936 & $1: 50000$ & 1.95 \\
\hline Orthophotographic base map & 1988 & $1: 5000$ & 1.53 \\
& 1996 & & 1.50 \\
\hline Aerial photograph & 1962 & $1: 5000$ & 1.75 \\
& 2005 & & 1.61 \\
\hline
\end{tabular}

ing the relation between cliff recession and talus deposition patterns.

\subsection{Design of Physical Modeling}

The rockfall area in Xiangshan can be subdivided into three regions: the source area, the movement area, and the deposition area. In this research, simplified physical modeling tests were conducted in order to obtain major talus deposition features caused by different rock amount, two slope angles and two fall types. Items considered for the setting of a physical model included the selection of materials, the design of equipment in each region of a rockfall area, and measurement apparatuses. A small scale model at $1: 160$ scale was built to simulate a simplified rockfall and talus deposition behavior. As shown in Fig. 3, the source area was composed of a cylindrical container with a shutter at the bottom, opening of the shutter allows the contents to fall freely. The slope angle of the run-out area could be adjusted to simulate the inclination of the original topographic slope (that is the basal surface beneath the talus sediment). Therefore the original topographic slope on the deposition features and patterns could be investigated. The deposition area was designed to provide enough space for the final deposition of fallen materials.

\subsection{Setting of the Physical Modeling}

\subsubsection{Selection of Materials}

A physical modeling test depends on the selection of representative rock materials. Field investigation revealed that the dimension of the deposition rocks at Xiangshan ranged from 0.3 to $15 \mathrm{~m}$, with rocks in the range of 0.3 $0.5 \mathrm{~m}$ comprising the majority at $50 \%$ of the total. In accordance, granular gravels of $0.2-0.3 \mathrm{~cm}$ were used to simulate real rock materials after a tentative trial (Fig. 3).

\subsubsection{The Source Area Setting}

The source area simulation comprised a $39 \mathrm{~cm}$ long releasing cylindrical container $5.5 \mathrm{~cm}$ in diameter mounted plumb vertical. The simulation movement area and the deposition area were set directly underneath the releasing cylindrical container (Fig. 3). Experiments were carried out under control over the quantity and the falling height of rock materials in order to simulate two fall types. Opening the retaining shutter of the container released the materials and all material fell freely and simultaneously hit the run-out area or the deposition area, leading to a fan-shaped deposition spread.

\subsubsection{Setting the Run-Out Area and Deposition Area}

As shown in Fig. 3, the movement area was composed of a $20 \times 60 \mathrm{~cm}$ (length $\times$ width) plane the slope angle of which was adjustable between 30 to 90 degrees. The deposition area was composed of a $60 \times 120 \mathrm{~cm}$ (length $\times$ width) plane that could provide enough space for allow deposition of falling materials.

\subsubsection{Measurement Apparatus}

The movement of falling materials and the deposition features were measured by digital video cameras with a six million pixel and recording rate of up to 30 frames per second. The measurement parameters included the front depo- 
sition length ( $\mathrm{L}$, the location between the end of movement area and the toe of talus deposit), the back deposition length ( $\mathrm{B}$, the location between the apex of talus deposit and the end of movement area), the deposition width (W), slope an- gle $\left(\alpha_{0}\right)$, and the deposition angles $(\alpha, \beta, \gamma)$. Generally, the geometry of a deposition pattern observed from side-view appeared as a curve, in this research the pattern is simplified into three straight line segments (Fig. 4).

\section{Material : Gravel $(0.2 \sim 0.3 \mathrm{~cm})$}

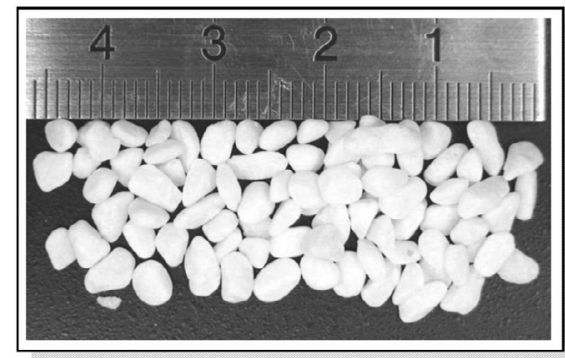

$/=\frac{\mathbf{D V}}{\mathrm{N}}$<smiles></smiles>

Deposition height
Camera

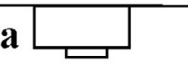

Camera

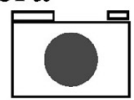

Deposition angle $(\alpha, \beta, \gamma)$

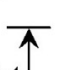

\section{$5.5 \mathrm{~cm}$}

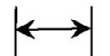

$39 \mathrm{~cm}$

Fig. 3. An illustration of the physical modeling test and materials.
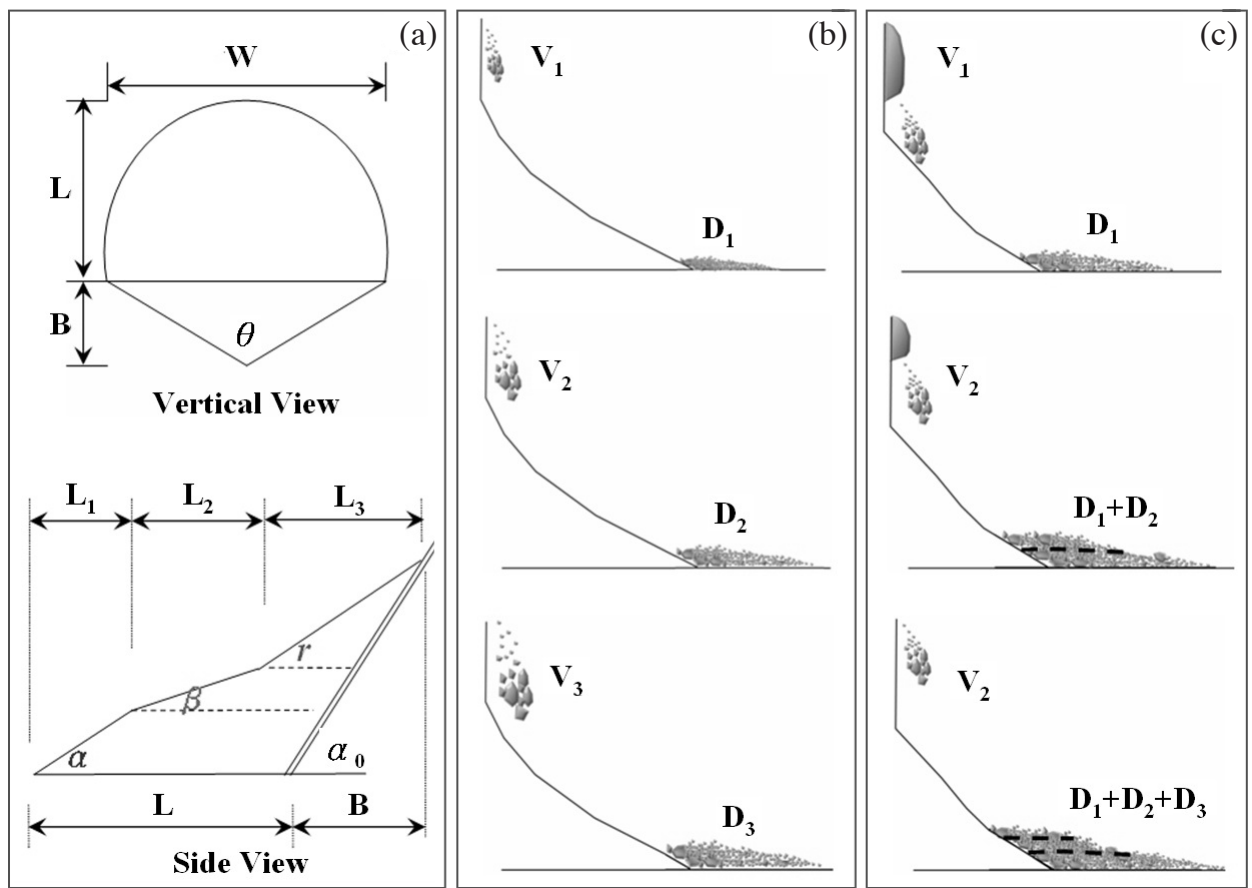

Fig. 4. An illustration of measurement parameters and two fall types in a physical modeling test: (a) the measurement parameters, including the front deposition length (L), the back deposition length (B), the deposition width (W), and the deposition angles $(\alpha, \beta, \gamma)$; (b) the simultaneous cluster fall test; (c) The sequential sub-cluster fall test. 


\subsection{Experimental Items}

(1) The amounts of rocks: By the different amounts of rocks, categorized as 961, 2884, 4810, 6730, 9615, and 12500 rocks, various talus deposition features were formed and discussed.

(2) The slope angles: According to the topographic maps in Xiangshan for the years 1904 and 1936, slope angles for the eastern cliff with an cataclinal slope of about 30 degrees and for the western cliff with an anaclinal slope of about 45 degrees were estimated. The slope angles of physical models were set as 30 and 45 degrees to simulate the original eastern and western topographic surface field, respectively.

(3) The fall types: This study investigated two fall types of cliff retreat: (a) a cluster fall (CF): a cluster of rock blocks falling simultaneously from the cliff; and (b) a sequential sub-cluster fall (SSCF): six sequential fall of rock blocks separated by joint sets or beddings.

\section{RESULTS}

\subsection{Results of Field Investigation and Geomorphic Analysis in Xiangshan}

\subsubsection{Cliff Joints}

Based on the field survey of representative sandstone outcrops of the cliffs and the results of aerial photograph interpretation with the LiDAR DSM at Xiangshan, four sets of joints were found and analyzed by Dip software (Fig. 5). The orientations for Joints A, B, C, and D were N55E/77S, N13E/75E, N40W/75E, and N77W/80N respectively. The orientation for the bedding surface was N53E/25S measured from the four representative outcrops. The spacing of each joint set and other geometric features were roughly estimated in the field and are listed in Table 3.

\subsubsection{Comparison of Cliff Recession Rates}

In order to investigate the temporal and spatial changes of the recession rates at Xiangshan, 8 survey lines (No. 1 - 4 on eastern cliffs and No. 5 - 8 on western cliffs) perpendicular to the cliffs with reference to Fig. 6a have been produced to record the recession rates for five different periods; 1904 to 1936,1936 to 1962,1962 to 1988,1988 to 1996 , and 1996 to 2005 . The calculated data of recession rates were presented in Fig. $6 \mathrm{~b}$ and Table 4. The results showed that the errors decreased as the version of maps became more recent. When the recession distance calculated at the cliff line was smaller than the location error interpolated from the three nearest ground control points, the cliff recession was insignificant during this period of time. In addition, the results showed that the most severe recession occurred between 1904 and 1936 with recession rate up to $2.13 \mathrm{~m}$ per year, followed by another significant recession rate up to $1.44 \mathrm{~m}$ per year between 1988 and 1996. The results also indicated that the recession rates on the eastern cliffs were generally larger than that of western cliffs.

\subsubsection{Typical Cliff Recession Profiles}

Based on field investigation and geomorphic analysis between different time intervals, five typical profiles (ABC on eastern cliffs and DE on western cliffs) describing the cliff recession mechanism were identified at Xiangshan (Fig. 7). A - A' profile had the most severe recession with a recession rate average of $0.89 \mathrm{~m}$ per year, followed by the B - B' profile with a recession rate average of $0.88-1.02 \mathrm{~m}$ per year. The C - C' profile had the third most severe recession with a recession rate average of $0.55 \mathrm{~m}$ per year, followed by the E - E' profile with a recession rate of 0.51 $-0.53 \mathrm{~m}$ per year. The least severe recession occurred in the D - D' profile with a recession rate of $0.29-0.30 \mathrm{~m}$ per year (Table 4). It was revealed that an eastern cataclinal slope usually had a higher recession rate than that of the western anaclinal slope (Fig. 7). Long-term exposure to in-situ human disturbance and stream erosion at the toe of the talus fan has since obscured some the features of talus deposits on the eastern slope at profiles A - A', B - B'.

(a) The A - A' profile was located on the south of the eastern cliff and relatively lowest location. The cliff experienced progressive headward erosion, and the erosion gullies shown in Fig. 1 carried a large volume of water. The sandstone shale interbeds located at the cliff toe behind the cliff face had been exposed to differential erosion, and was undercut by $2 \mathrm{~m}$. As such, the recession mechanism was considered to be one dominated by high ground water seepage that acted together with tension cracks on cliff top, and intense differential erosion.

(b) The B - B' profile was located in the center on the souther edge of the eastern cliff. Erosion gullies occurred on the upper slope over the cliff. The cliff toe was exposed to differential erosion, and was undercut by $1 \mathrm{~m}$. The recession mechanism here was considered to be one dominated by medium ground water seepage acting together with the tension cracks at the cliff top to exert moderate differential erosion.

(c) The C - C' profile was located on the north of eastern cliff with a relatively higher location compared to the $\mathrm{B}$ - B' and A - A' profiles. Talus deposits lay atop a colluvial deposit of great volume below the cliff. A complete sequence of alternating sandstone and shale interbeds was exposed near the run-out area. Groundwater seepage was insignificant on the slope and cliff face. The recession mechanism here was considered to be dominated only by tension cracks on the cliff top. 

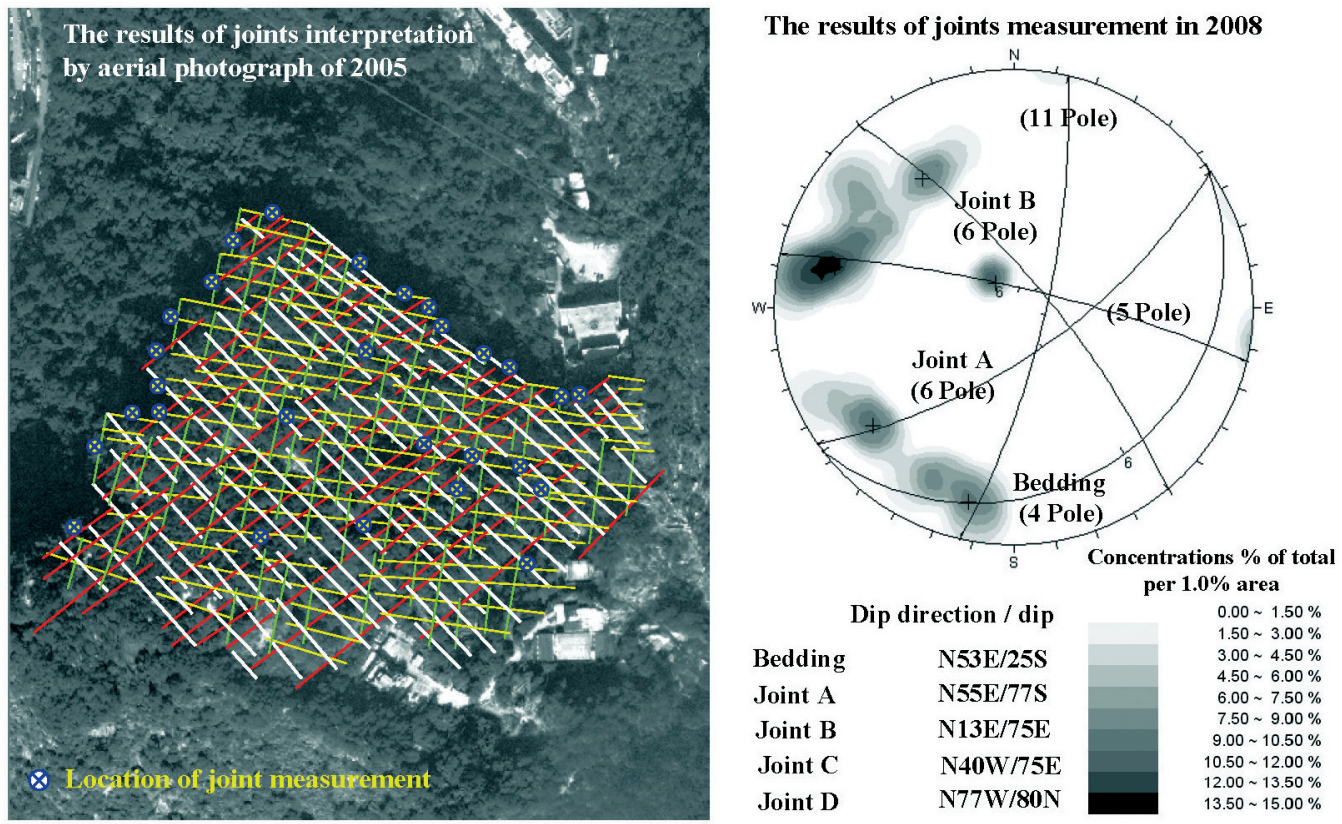

Fig. 5. The orientation of joints and bedding plane at Xiangshan identified by aerial photography (2005) and field investigation (Joints A-red; B-green; C-white; D-yellow).

Table 3. The results of cliff retreat mechanism and talus deposition features based upon field investigation and geomorphic analysis.

\begin{tabular}{|c|c|c|c|c|c|c|}
\hline & & \multicolumn{3}{|c|}{ Eastern cliff } & \multicolumn{2}{|c|}{ Western cliff } \\
\hline & & $\begin{array}{l}\text { A - A } \\
\text { profile }\end{array}$ & $\begin{array}{l}\text { B - B' } \\
\text { profile }\end{array}$ & $\begin{array}{l}\mathrm{C}-\mathrm{C} \\
\text { profile }\end{array}$ & $\begin{array}{l}\text { D - D' } \\
\text { profile }\end{array}$ & $\begin{array}{l}\text { E - E' } \\
\text { profile }\end{array}$ \\
\hline \multirow{6}{*}{ 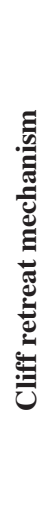 } & $\begin{array}{l}\text { The apparent of the bedding and } \\
\text { spacing of the joints }\end{array}$ & Cataclinal slope & Cataclinal slope & Cataclinal slope & Anaclinal slope & Anaclinal slope \\
\hline & & $5-10 m$ & $5-8 m$ & $3-5 \mathrm{~m}$ & $5-10 m$ & $5-10 m$ \\
\hline & $\begin{array}{l}\text { The thickness of upper sandstone } \\
\text { (Shiti sandstone) }\end{array}$ & $15-20 \mathrm{~m}$ & $20-25 m$ & $25-30 \mathrm{~m}$ & $25-30 \mathrm{~m}$ & $25-30 \mathrm{~m}$ \\
\hline & $\begin{array}{l}\text { The thickness of inter-bedded } \\
\text { layer crop above the apex of the } \\
\text { talus slope (Sandstone-shale inter- } \\
\text { bedding) }\end{array}$ & $5-8 m$ & $5-10 m$ & $10-15 \mathrm{~m}$ & $10-15 \mathrm{~m}$ & $5-10 m$ \\
\hline & Ground water seepage & High & Medium & Low & Low & Medium \\
\hline & The degree of differential erosion & High & Medium & Low & Low & Medium \\
\hline \multirow{8}{*}{ 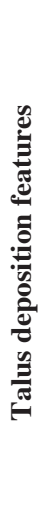 } & Original slope angle & $20-25$ & $25-30$ & $30-35$ & $45-50$ & $40-45$ \\
\hline & $\mathrm{L}$ & $10-20 \mathrm{~m}$ & $10-25 \mathrm{~m}$ & $5-15 m$ & $15-45 \mathrm{~m}$ & $15-30 \mathrm{~m}$ \\
\hline & W & $30-75 \mathrm{~m}$ & $30-80 \mathrm{~m}$ & $40-80 \mathrm{~m}$ & $10-45 \mathrm{~m}$ & $10-55 \mathrm{~m}$ \\
\hline & B & $20-45 m$ & $10-50 \mathrm{~m}$ & $10-35 \mathrm{~m}$ & $5-30 m$ & $10-35 \mathrm{~m}$ \\
\hline & $\alpha$ & $20-25^{\circ}$ & $15-20^{\circ}$ & $30-36^{\circ}$ & $30-35^{\circ}$ & $25-30^{\circ}$ \\
\hline & $\beta$ & $30-35^{\circ}$ & $25-30^{\circ}$ & $20-25^{\circ}$ & $30-35^{\circ}$ & $25-30^{\circ}$ \\
\hline & $\gamma$ & $5-8^{\circ}$ & $5-8^{\circ}$ & $10-15^{\circ}$ & $35-45^{\circ}$ & $30-35^{\circ}$ \\
\hline & Rock dimensions & $0.2-15 \mathrm{~m}$ & $0.2-15 \mathrm{~m}$ & $0.2-5 \mathrm{~m}$ & $0.2-8 \mathrm{~m}$ & $0.1-3 \mathrm{~m}$ \\
\hline
\end{tabular}


(d) The D - D' profile was located on the north of the western cliff with a relatively higher location compared to the C - C' profile. Accumulations of huge, elongated sandstone blocks were readily observed below the cliff. In addition, the tension cracks on the cliff top were also significant. Therefore, the recession mechanism here was considered to be one dominated by tension cracks on the cliff top rather than ground water seepage.

(e) The E-E' profile was located on the south of the western cliff. The cliff top had undergone severe headward erosion, this is manifested by a cave with arched, curved side-walls. Talus deposits were composed of blocks of rocks smaller than those of the D - D' profile. Therefore, the recession mechanism was considered to be one dominated by tension cracks on the cliff top, and the high intensity of differential erosion due to ground water seepage.

\subsubsection{Talus Deposition Features in the Field}

Based on field investigation and geomorphic analysis, the cliffs at Xiangshan where talus deposits were located (a)

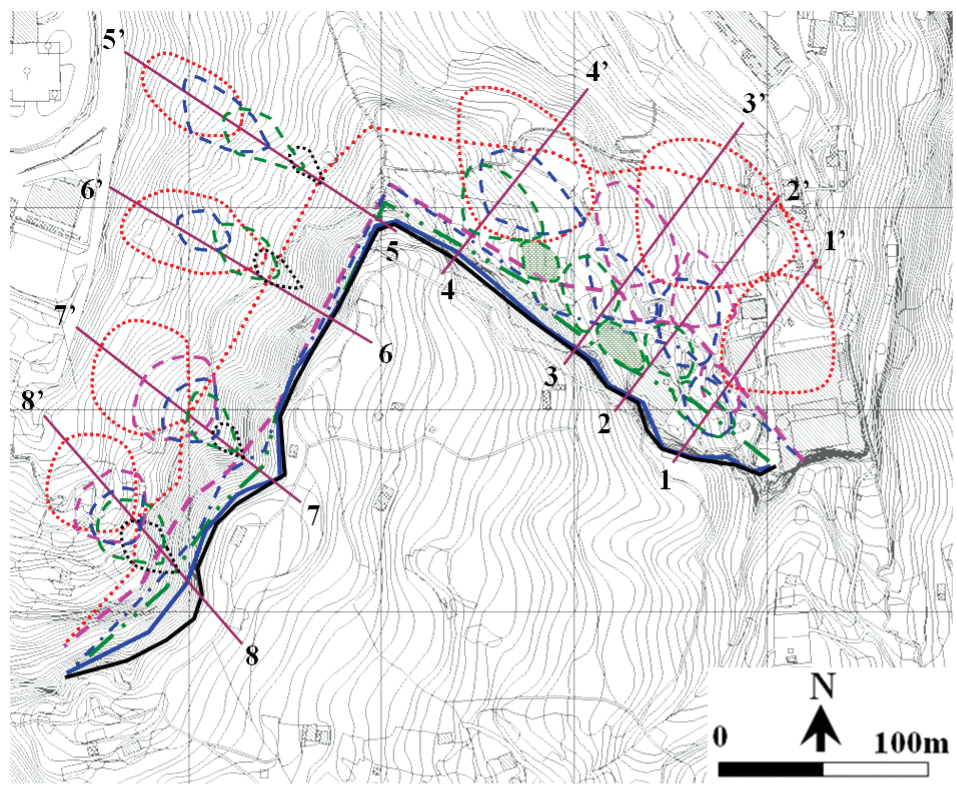

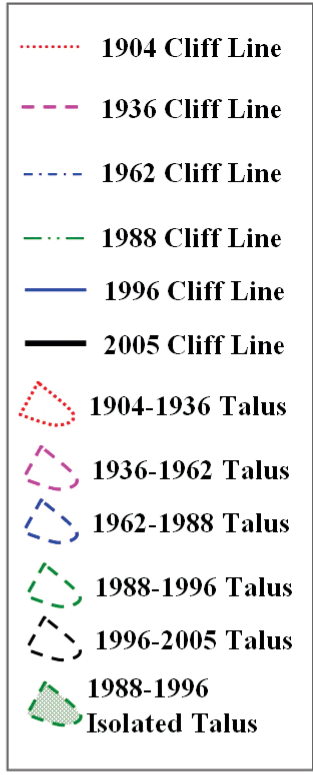

(b)

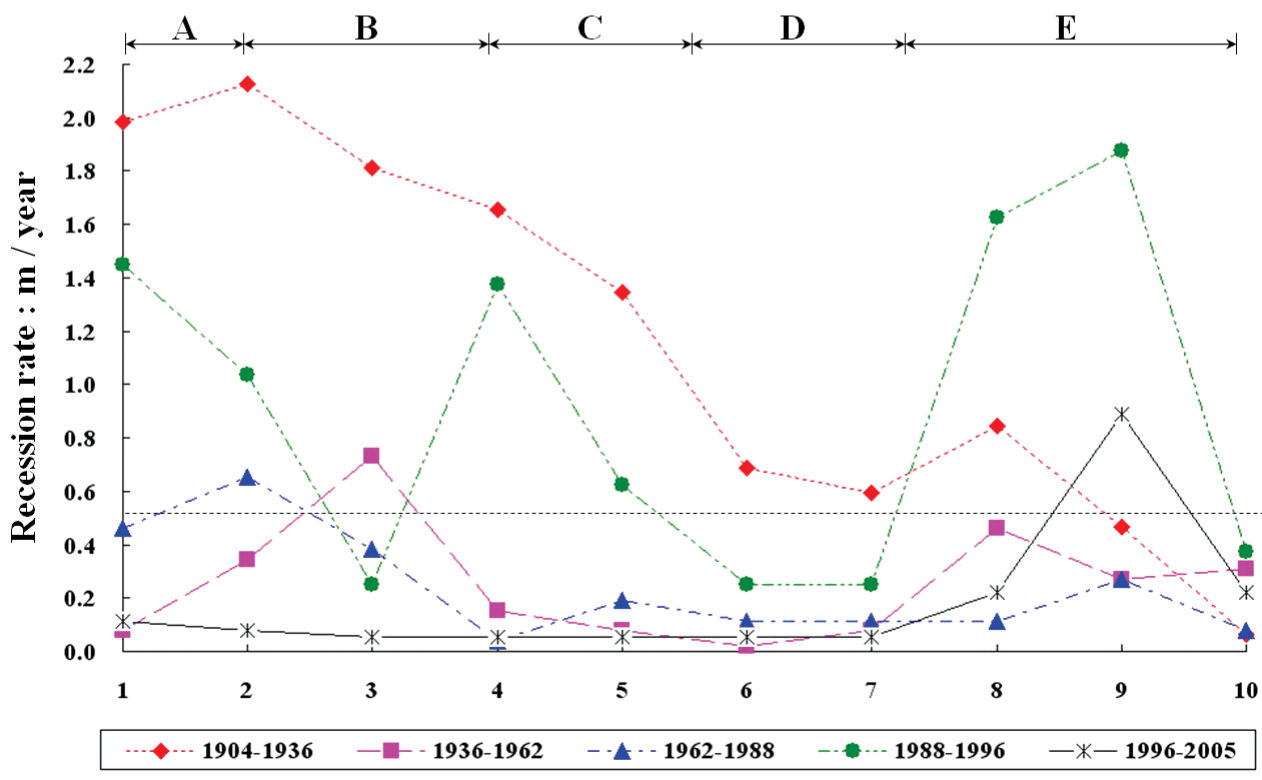

Measurement station no.

Fig. 6. (a) The location of cliff lines and talus deposits at Xiangshan at different time periods (top view), the locations of 8 marked survey lines. (b) The cliff recession rate of 8 profiles at different time periods (A - E are typical cliff recession profiles as shown in Fig. 7). 
Table 4. Cliff recession rate and talus deposition features revealed by 8 profile lines depicting Xiangshan.

\begin{tabular}{|c|c|c|c|c|c|c|c|c|}
\hline $\begin{array}{l}\text { Profile } \\
\text { Number }\end{array}$ & $\begin{array}{l}\text { Typical cliff } \\
\text { recession profile }\end{array}$ & \multicolumn{2}{|c|}{ Recession rate $\left(\mathrm{m} \mathrm{yr}^{-1}\right)$} & $\begin{array}{c}\text { Recession } \\
\text { distance }(\mathbf{m})\end{array}$ & Error (m) & $\begin{array}{l}\text { Significant } \\
\text { periods of cliff } \\
\text { recession }\end{array}$ & Fall type & $\begin{array}{c}\text { Talus } \\
\text { deposition } \\
\text { patterns }\end{array}$ \\
\hline \multirow{6}{*}{$\begin{array}{c}1 \\
\left(1-1^{\prime}\right)\end{array}$} & \multirow{6}{*}{$\begin{array}{l}\text { A - A' } \\
\text { profile }\end{array}$} & $1904-1936$ & 1.98 & 65.34 & 5.79 & \multirow{6}{*}{$\begin{array}{l}1904-1936 \\
1962-1988 \\
1988-1996\end{array}$} & \multirow{6}{*}{$\begin{array}{l}\text { sequential } \\
\text { sub-cluster } \\
\text { fall (SSCF) }\end{array}$} & \multirow{6}{*}{ II- $30^{\circ}$} \\
\hline & & $1936-1962$ & 0.08 & 2.16 & 3.25 & & & \\
\hline & & $1962-1988$ & 0.46 & 12.42 & 2.98 & & & \\
\hline & & $1988-1996$ & 1.45 & 11.60 & 2.69 & & & \\
\hline & & $1996-2005$ & 0.11 & 0.99 & 2.65 & & & \\
\hline & & $1904-2005$ & 0.89 & 90.78 & 17.36 & & & \\
\hline \multirow{6}{*}{$\begin{array}{c}2 \\
(2-2 ')\end{array}$} & \multirow{6}{*}{$\begin{array}{l}\text { B - B' } \\
\text { profile }\end{array}$} & $1904-1936$ & 2.13 & 70.29 & 5.77 & \multirow{6}{*}{$\begin{array}{l}1904-1936 \\
1936-1962 \\
1962-1988 \\
1988-1996\end{array}$} & \multirow{6}{*}{$\begin{array}{l}\text { sequential } \\
\text { sub-cluster } \\
\text { fall (SSCF) } \\
\text { cluster fall } \\
(\mathrm{CF})\end{array}$} & \multirow{6}{*}{$\begin{array}{l}\mathrm{I}-30^{\circ} \\
\mathrm{II}-30^{\circ}\end{array}$} \\
\hline & & $1936-1962$ & 0.35 & 9.45 & 3.23 & & & \\
\hline & & $1962-1988$ & 0.65 & 17.55 & 2.97 & & & \\
\hline & & $1988-1996$ & 1.04 & 9.36 & 2.69 & & & \\
\hline & & $1996-2005$ & 0.08 & 0.80 & 2.66 & & & \\
\hline & & $1904-2005$ & 1.02 & 104.04 & 17.31 & & & \\
\hline \multirow{6}{*}{$\begin{array}{c}3 \\
\left(3-3^{\prime}\right)\end{array}$} & \multirow{6}{*}{$\begin{array}{l}\text { B - B' } \\
\text { profile }\end{array}$} & $1904-1936$ & 1.81 & 59.73 & 5.48 & \multirow{6}{*}{$\begin{array}{l}1904-1936 \\
1936-1962 \\
1962-1988\end{array}$} & \multirow{6}{*}{$\begin{array}{l}\text { sequential } \\
\text { sub-cluster } \\
\text { fall (SSCF) } \\
\text { cluster fall } \\
(\mathrm{CF})\end{array}$} & \multirow{6}{*}{$\begin{array}{l}\mathrm{I}-30^{\circ} \\
\mathrm{II}-30^{\circ}\end{array}$} \\
\hline & & $1936-1962$ & 0.73 & 19.71 & 3.03 & & & \\
\hline & & $1962-1988$ & 0.38 & 10.26 & 2.77 & & & \\
\hline & & $1988-1996$ & 0.25 & 2.25 & 2.54 & & & \\
\hline & & $1996-2005$ & 0.06 & 0.60 & 2.54 & & & \\
\hline & & $1904-2005$ & 0.88 & 89.76 & 16.35 & & & \\
\hline \multirow{6}{*}{$\begin{array}{c}4 \\
\left(4-4^{\prime}\right)\end{array}$} & \multirow{6}{*}{$\begin{array}{l}\mathrm{C}-\mathrm{C}^{\prime} \\
\text { profile }\end{array}$} & $1904-1936$ & 1.34 & 44.22 & 5.49 & \multirow{6}{*}{$\begin{array}{l}1904-1936 \\
1962-1988 \\
1988-1996\end{array}$} & \multirow{6}{*}{$\begin{array}{l}\text { sequential } \\
\text { sub-cluster } \\
\text { fall (SSCF) }\end{array}$} & \\
\hline & & $1936-1962$ & 0.08 & 2.16 & 3.03 & & & \\
\hline & & $1962-1988$ & 0.19 & 5.13 & 2.77 & & & UI $30^{\circ}$ \\
\hline & & $1988-1996$ & 0.63 & 5.67 & 2.55 & & & $11-30$ \\
\hline & & $1996-2005$ & 0.06 & 0.60 & 2.55 & & & \\
\hline & & $1904-2005$ & 0.55 & 56.10 & 16.39 & & & \\
\hline & & $1904-1936$ & 0.82 & 27.06 & 5.49 & & & \\
\hline & & $1936-1962$ & 0.04 & 1.08 & 3.03 & & & \\
\hline 5 & D - D' & $1962-1988$ & 0.06 & 1,62 & 2.77 & $1004 \quad 1036$ & sequential & II $15^{\circ}$ \\
\hline$\left(5-5^{\prime}\right)$ & profile & $1988-1996$ & 0.08 & 0.72 & 2.56 & $1904-1950$ & fall (SSCF) & $11-45$ \\
\hline & & $1996-2005$ & 0.15 & 1.50 & 2.55 & & & \\
\hline & & $1904-2005$ & 0.30 & 30.6 & 16.40 & & & \\
\hline & & $1904-1936$ & 0.69 & 22.77 & 5.48 & & & \\
\hline & & $1936-1962$ & 0.02 & 0.54 & 3.02 & & & \\
\hline 6 & D - D' & $1962-1988$ & 0.06 & 1.62 & 2.76 & $1904-1936$ & sequential & U- $45^{\circ}$ \\
\hline$(6-6 ’)$ & profile & $1988-1996$ & 0.25 & 2.25 & 2.54 & $1996-2005$ & fall (SSCF) & $11-45$ \\
\hline & & $1996-2005$ & 0.35 & 3.50 & 2.54 & & & \\
\hline & & $1904-2005$ & 0.29 & 29.58 & 16.34 & & & \\
\hline & & $1904-1936$ & 0.84 & 27.72 & 5.33 & & & \\
\hline & & $1936-1962$ & 0.46 & 12.42 & 2.83 & 1904 & & \\
\hline 7 & $E-E^{\prime}$ & $1962-1988$ & 0.12 & 3.24 & 2.55 & $1936-1962$ & sequential & 4 \\
\hline$(7-7 ’)$ & profile & $1988-1996$ & 1.23 & 11.07 & 2.37 & $1962-1988$ & fall (SSCF) & $11-45$ \\
\hline & & $1996-2005$ & 0.22 & 2.20 & 2.41 & $1988-1996$ & & \\
\hline & & $1904-2005$ & 0.53 & 54.06 & 15.49 & & & \\
\hline & & $1904-1936$ & 0.47 & 15.51 & 5.28 & & & \\
\hline & & $1936-1962$ & 0.27 & 7.29 & 2.80 & $1904-1936$ & & \\
\hline 8 & $E-E^{\prime}$ & $1962-1988$ & 0.27 & 7.29 & 2.51 & $1936-1962$ & sequential & \\
\hline$\left(8-8^{\prime}\right)$ & profile & $1988-1996$ & 1.44 & 12.96 & 2.34 & $\begin{array}{l}1902-1988 \\
1988-1996\end{array}$ & $\begin{array}{l}\text { sub-ciuster } \\
\text { fall (SSCF) }\end{array}$ & $11-45^{\circ}$ \\
\hline & & $1996-2005$ & 1.18 & 11.80 & 2.38 & $1996-2005$ & & \\
\hline & & $1904-2005$ & 0.51 & 52.02 & 15.31 & & & \\
\hline
\end{tabular}



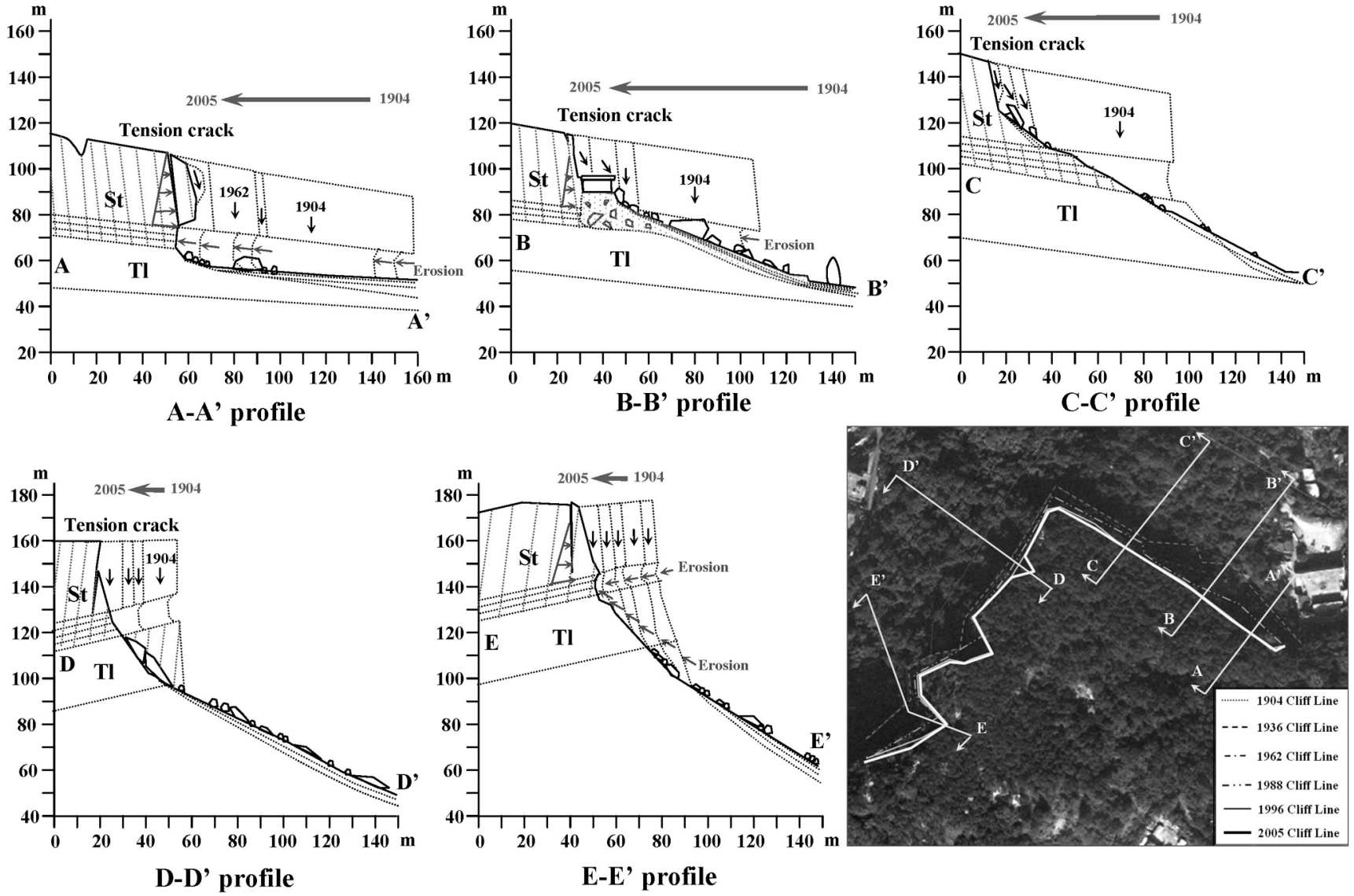

Fig. 7. Five cliff recession profiles at Xiangshan, Taipei.

were subdivided into two categories, the eastern cliff and the western cliff (Table 3 ). The measurement parameters of talus deposition features include the front deposition length (L), the back deposition length (B), the deposition width (W), and the deposition angles $(\alpha, \beta, \gamma)$ (Fig. 4).

(a) The eastern cliff: Talus deposits were broadly fanshaped; the top of the deposition zone inclined gently whereas the toe had a steeper inclination. In the northern half of the eastern cliff, Talus deposits were broadly fanshaped and were deposited on existing colluviums

(b) The western cliff: Talus deposits were long and narrowly fan-shaped and were distributed over four main areas; the deposition angles inclined rather strongly.

\subsection{Results of Deposition Features and Patterns by Physical Modeling Test}

The results of deposition features and patterns obtained from the physical modeling tests are noted in Figs. 8 - 9, and Table 4 . The results of simultaneous cluster fall tests (I) are shown in Fig. 8 and Table 4a. The results of the sequential sub-cluster fall (II) are shown in Fig. 9 and Table $4 \mathrm{~b}$. Tests I- $30^{\circ}$, II- $30^{\circ}$ and I- $45^{\circ}$, II- $45^{\circ}$ denoted an assigned slope angle of $30^{\circ}$ and $45^{\circ}$, respectively. These four deposition patterns were used to categorize the deposition patterns observed in Xiangshan.

\subsubsection{Influence of Rock Amount}

In order to understand the influence of rock volume on the deposition features, the geometric parameters $(\mathrm{L}, \mathrm{W}, \mathrm{B}$, $\alpha, \beta, \gamma)$ of various rock volume normalized with maximum values obtained from those of the maximum rock volume are listed in Table 5. The wider the range of these normalized parameters, the more sensitive these parameters were to influence various rock volume.

I. Simultaneous cluster fall tests: According to the variation of parameters of normalization (Table 5) of various rock volumes, while the falling rocks increased on the original slope of $30^{\circ}$, the deposition features show that the variation of parameters ranking from the most significant to the most insignificant variations would be $\beta, \mathrm{B}, \alpha, \mathrm{W}, \mathrm{L}, \gamma$; whereas, for original slope of $45^{\circ}$, the rank order of parameters would be $\gamma, \beta, \mathrm{L}, \mathrm{W}, \mathrm{B}, \alpha$, respectively.

II. Sequential sub-cluster fall tests: While falling rock increased the original slope of $30^{\circ}$, the deposition features 

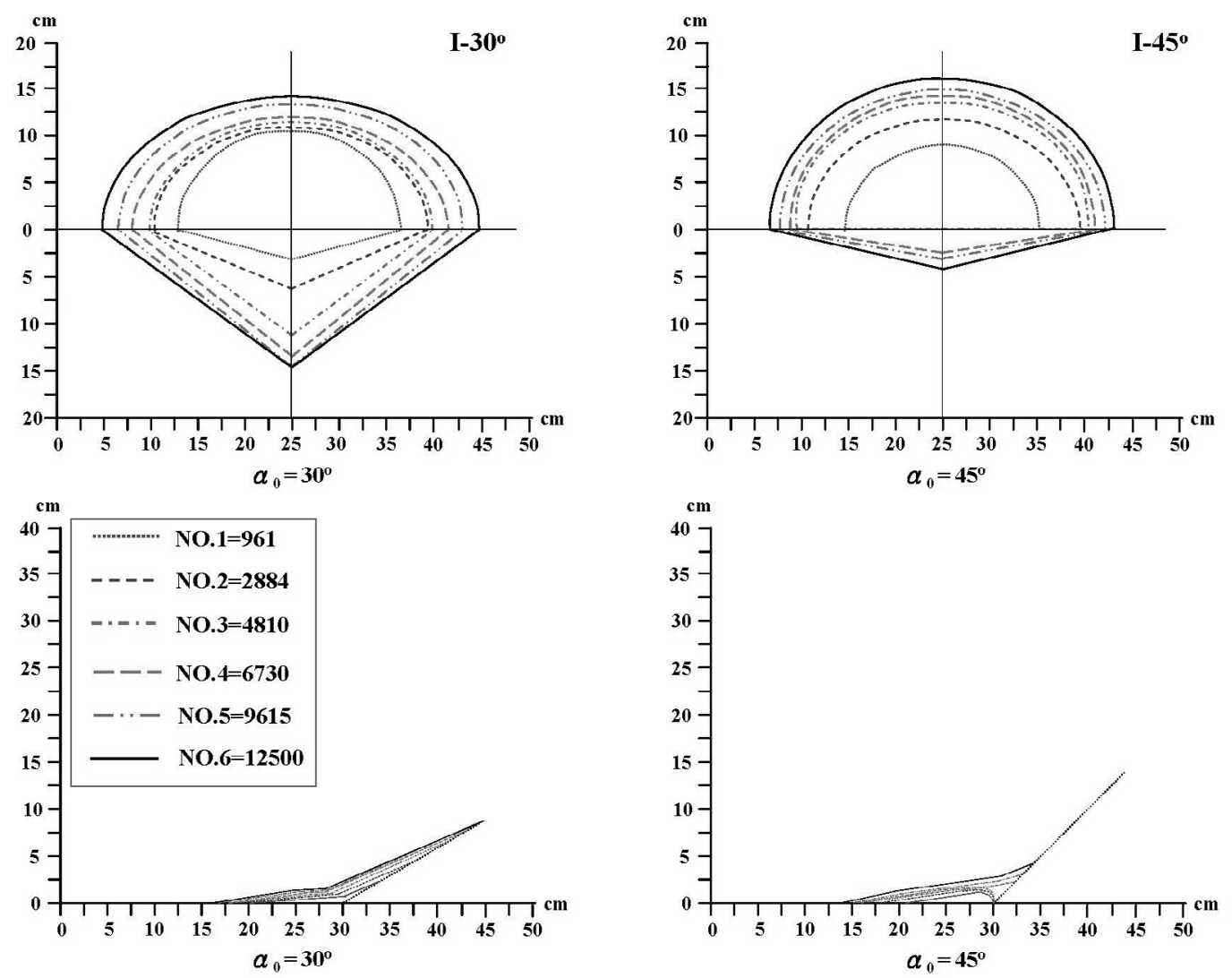

Fig. 8. Talus deposition features exhibited by simultaneous cluster fall tests (vertical view and side view).
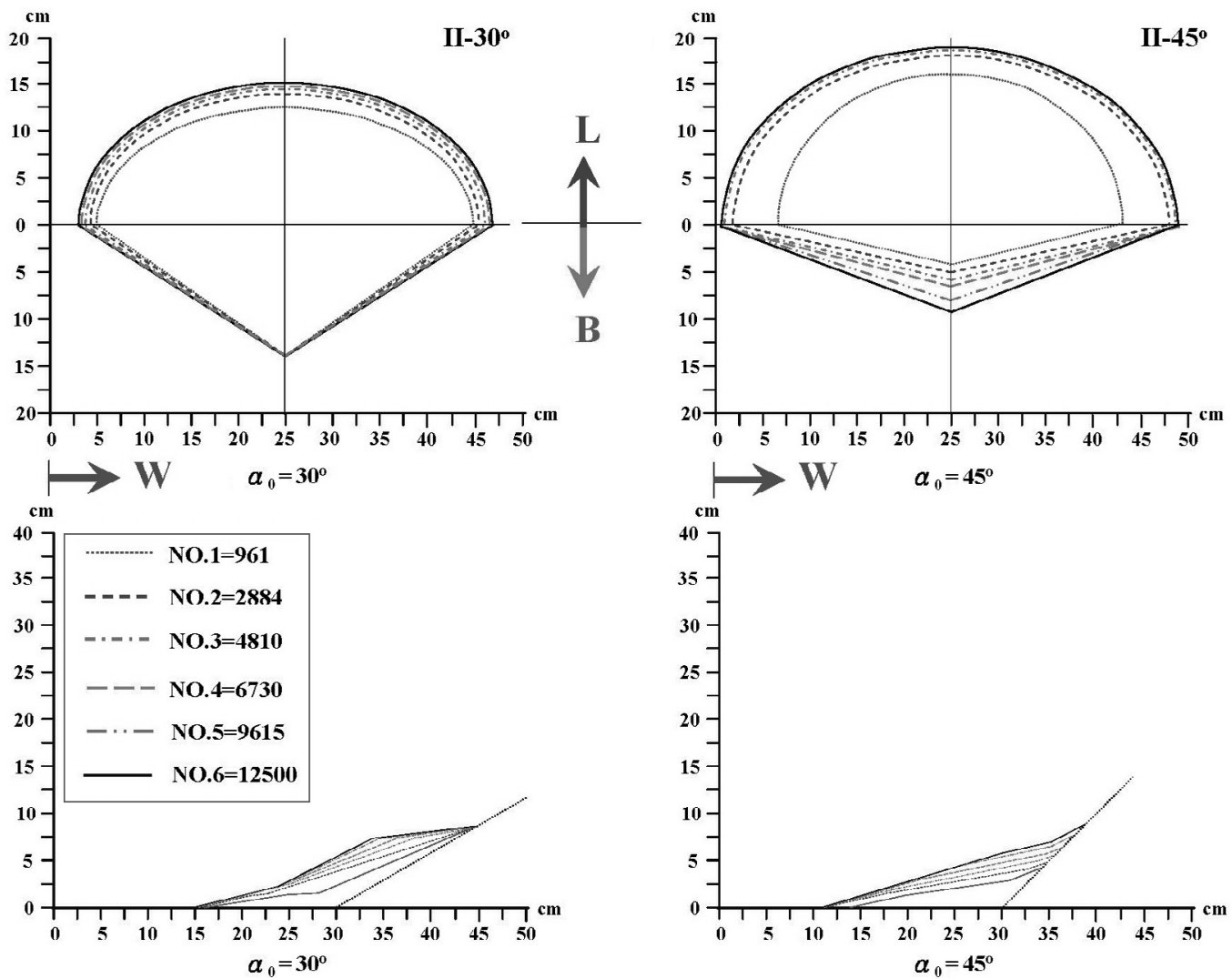

Fig. 9. Talus deposition features by sequential sub-cluster fall tests (vertical view and side view). 
Table 5. The results of talus deposition features by physical model experiment.

(a) the results of the cluster falling simultaneously tests

$\mathbf{I}-30^{\circ}$

$\begin{array}{llllll}\mathbf{L}_{\mathrm{n}} & \mathbf{W}_{\mathrm{n}} & \mathbf{B}_{\mathrm{n}} & \boldsymbol{\alpha}_{\mathrm{n}} & \boldsymbol{\beta}_{\mathrm{n}} & \boldsymbol{\gamma}_{\mathrm{n}}\end{array}$

$\begin{array}{llllllll}\mathbf{L} & \mathbf{W} & \mathbf{B} & \boldsymbol{\alpha} & \boldsymbol{\beta} & \boldsymbol{\gamma} & \text { The variation of parameters }\end{array}$

$\begin{array}{llllll}5 & 4 & 2 & 3 & 1 & 6\end{array}$

$\mathbf{I}-45^{\circ}$

$\begin{array}{llllll}\mathbf{L}_{\mathrm{n}} & \mathbf{W}_{\mathrm{n}} & \mathbf{B}_{\mathrm{n}} & \boldsymbol{\alpha}_{\mathrm{n}} & \boldsymbol{\beta}_{\mathrm{n}} & \boldsymbol{\gamma}_{\mathrm{n}}\end{array}$

$\begin{array}{lllllllll}\mathbf{L} & \mathbf{W} & \mathbf{B} & \boldsymbol{\alpha} & \boldsymbol{\beta} & \gamma\end{array}$
The variation of parameters

$\begin{array}{llllll}3 & 4 & 5 & 6 & 2 & 1\end{array}$

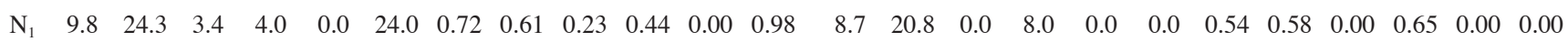

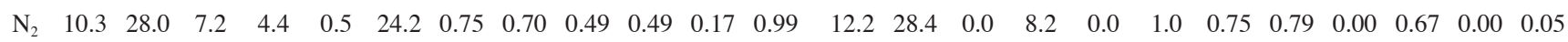

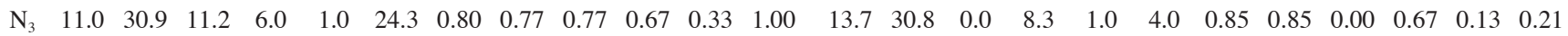
$\begin{array}{lllllllllllllllllllllllll}\mathrm{N}_{4} & 12.1 & 34.2 & 13.0 & 7.2 & 2.0 & 24.3 & 0.88 & 0.86 & 0.89 & 0.80 & 0.67 & 1.00 & 14.3 & 32.4 & 2.5 & 9.0 & 3.0 & 10.0 & 0.88 & 0.90 & 0.56 & 0.73 & 0.38 & 0.53\end{array}$

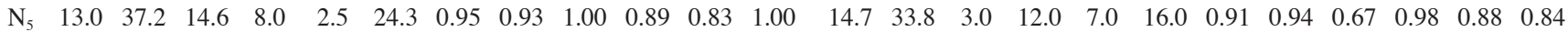

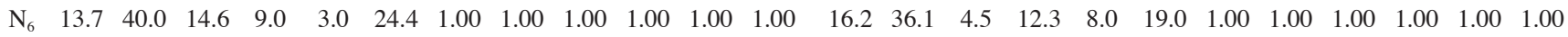

(b) the results of the sub-cluster falling in sequence tests

II-30 ${ }^{\circ}$

$\begin{array}{llllll}\mathbf{L}_{\mathrm{n}} & \mathbf{W}_{\mathrm{n}} & \mathbf{B}_{\mathrm{n}} & \boldsymbol{\alpha}_{\mathrm{n}} & \boldsymbol{\beta}_{\mathrm{n}} & \boldsymbol{\gamma}_{\mathrm{n}}\end{array}$

$\begin{array}{lllllll}\mathbf{L} & \mathbf{W} & \mathbf{B} & \boldsymbol{\alpha} & \boldsymbol{\beta} & \boldsymbol{\gamma}\end{array}$

\section{The variation of parameters}

II-45

$\begin{array}{llllll}\mathbf{L}_{\mathrm{n}} & \mathbf{W}_{\mathrm{n}} & \mathbf{B}_{\mathrm{n}} & \boldsymbol{\alpha}_{\mathrm{n}} & \boldsymbol{\beta}_{\mathrm{n}} & \boldsymbol{\gamma}_{\mathrm{n}}\end{array}$
The variation of parameters

$\begin{array}{llllll}6 & 5 & 1 & 3 & 4 & 2\end{array}$

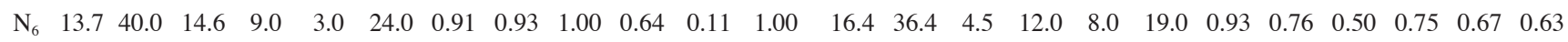

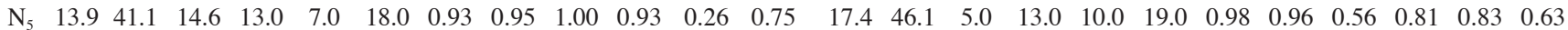

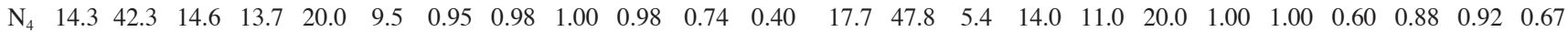

$\begin{array}{lllllllllllllllllllllllll}\mathrm{N}_{3} & 14.7 & 42.9 & 14.6 & 14.0 & 22.0 & 7.5 & 0.98 & 1.00 & 1.00 & 1.00 & 0.81 & 0.31 & 17.7 & 48.0 & 7.0 & 15.0 & 12.0 & 24.0 & 1.00 & 1.00 & 0.78 & 0.94 & 1.00 & 0.80\end{array}$

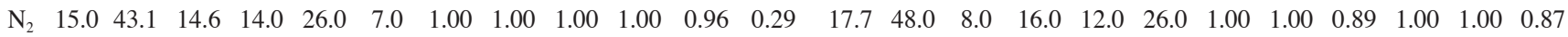

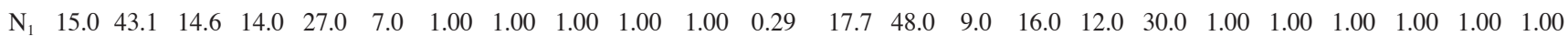

\section{Note:}

(1) Unit of $L, W, B$ : Centimeter; Unit of $\alpha, \beta, \gamma:$ Degree.

(2) N: Number of rock $\left(N_{1}=961 ; N_{2}=2884 ; N_{3}=4810 ; N_{4}=6730 ; N_{5}=9615 ; N_{6}=12500\right)$.

(3) $\frac{L_{i}}{L_{\max }}=L_{n} ; \frac{W_{i}}{W_{\max }}=W_{n} ; \frac{B_{i}}{B_{\max }}=B_{n} ; \frac{\alpha_{i}}{\alpha_{\max }}=\alpha_{n} ; \frac{\beta_{i}}{\beta_{\max }}=\beta_{n} ; \frac{\gamma_{i}}{\gamma_{\max }}=\gamma_{n}$. 
show that the variation of parameters ranking from the most significant to the most insignificant variations would be $\gamma$, $\beta, \alpha, \mathrm{L}, \mathrm{W}, \mathrm{B}$; whereas, for the original slope of $45^{\circ}$, the rank order of parameters would be $\mathrm{B}, \gamma, \alpha, \beta, \mathrm{W}, \mathrm{L}$, respectively (Table 5).

\subsubsection{Influence of Original Slope Angle}

I. Simultaneous cluster fall tests: The comparison of deposition features between the original $30^{\circ}$ slope angle (low slope) and original $45^{\circ}$ slope angle (high slope) is shown in Fig. 8. While the deposition volume increased, $\mathrm{W}$ and $\mathrm{B}$ on the low slope were significantly superior to those on the high slope. $L$ on the high slope was larger than that of the low slope. $\alpha$ and $\beta$ on the high slope were higher than those of the low slope. However, $\gamma$ on the low slope changed very slightly while falling rocks increased. These findings reflect that the parameters with the most significant variations would be the back deposition length and width on the low slope, as well as the deposition angles, the front deposition length and width on the high slope, respectively.

II. Sequential sub-cluster fall tests: The comparison of the deposition features between $30^{\circ}$ and $45^{\circ}$ of the original slope angles is shown in Fig. 9. While the deposition volume increased, $\mathrm{W}$ and $\mathrm{B}$ on the high slope were significantly superior to those on the lower slope. L changed very slightly on both the higher and lower slopes. $\alpha$ and $\beta$ increased on both the higher and lower slopes, where $\beta$ on the lower slope increased more significantly compared to the higher slope. However, $\gamma$ on the lower slope decreased, but increased on the higher slope.

Comparing the results of different fall types indicate that, on a lower slope, the deposition dimensions tend to broaden on the original slope surface and the deposition angles tend to become gentler near the apex and steeper near the toe. On the other hand, on a higher slope, the deposition dimensions tend to elongate and narrow on the original slope surface and the deposition angles tend to become steep.

\subsection{The Relationship between Cliff Recession and Talus Deposits at Xiangshan}

(1) According to physical modeling tests and geomorphic analysis, B - B' and D - D' profile lines (Fig. 7) were selected as an example to show the possible relationship between cliff recession and talus deposition development on eastern and western Xiangshan slopes, respectively (Fig. 10).

(a) B - B' profile: Due to the lower original topographic slope of B - B', the deposition pattern tended to consist of a broader deposition width (W), larger back deposition length (B), and shorter front deposition length (L). Speculating from the experience obtained from physical modeling tests, the deposition evolution of B - B' at four separate periods of time showed that $\gamma$ decreased and $\beta$ increased while the cliff retreated gradually (Figs. 6 and 10).

(b) D - D' profile: Due to the higher original topographic slope of D - D', the deposition pattern tended to consist of narrower deposition width (W), shorter back deposition length (B), and larger front deposition length (L). The deposition evolution of D - D' at four periods of time showed that $\alpha, \gamma$, and $\beta$ increased while the cliff retreated (Figs. 6 and 10).

(2) Summarizing the features and the mechanisms discussed above, the development of cliff recession and talus deposition at Xiangshan at five different periods of time (1904 - 1936, 1936 - 1962, 1962 - 1988, 1988 - 1996, and 1996 - 2005) was determined (Figs. 6a and 11) and summarized (Table 4). Based on geomorphic analysis aided with the experience obtained from physical modeling tests, eight profiles of cliff retreat and build up of talus deposits are proposed.

(3) Profile 1-1': The cliff line showed a tendency of persistent recession owing to two main factors: the intensely developed erosion gullies on the top of the cliff and undermining of thin interbeds underlying thick sandstone by groundwater that percolated through rock joints. The overall recession rate, at $0.89 \mathrm{~m}$, ranked second. Field investigation and geomorphic analysis showed cliff line recession and accumulation of rockfall deposit occurred in three periods, 1904 - 1936, 1962 - 1988, and 1988 1996. The deposit formed in 1904 - 1936 was the largest. Rockfall deposits from the periods1962 - 1988 and 1988 - 1996 were subsequently scattered on top of the existing talus deposits. The original inclination of the slope was quite gentle at $20-25^{\circ}$ and the deposit was spread sideways. The resultant deposit featured a gentler dipping upper slope at $5-8^{\circ}$, and steeper lower slope at $20-25^{\circ}$ with an overall appearance of $\mathrm{W}: \mathrm{L}: \mathrm{B}$ at $4: 1$ $: 2$. However, since the existing deposit was situated at the upstream section of the stream, materials at the toes of slope were carried downstream. Therefore, the lower part of deposition fan of profile 1 - 1' was significantly modified by human disturbance and stream erosion at the toe of the talus fan.

(4) Profiles 2 - 2' and 3-3': In these two profiles of cliff top erosion gullies were less intensely developed and the toe erosion was weaker than that of Profile $1-1$ '. Field investigation and geomorphic analysis indicated that cliff recession occurred in profile 2 - 2' in 1904 - 1936, 1936 - 1962, 1962 - 1988, and 1988 - 1996; whereas in profile 3 - 3', cliff recession occurred in 1904 - 1936, 1936 - 1962 and 1988. In both profiles the most severe cliff recession occurred in the period 1904 - 1936. The 
maximum average annual cliff recession rate in profile 2 - 2' was $1.02 \mathrm{~m}$ which was also the greatest overall cliff recession rate for all profiles. That of profile 3 - 3' came third at $0.88 \mathrm{~m}$. The earliest talus deposits in the lower slopes of these profiles were partly carried downstream. Owing to the 20 to $25^{\circ}$ inclination of the original runout slope, the deposit was spread sideways resulting in a thinner deposit of $2.5 \mathrm{~m}$ in thickness. The upper slope was gentler at inclination of $5-8^{\circ}$, and the steeper lower slope inclined at $25-30^{\circ}$. The $\mathrm{W}: \mathrm{L}: \mathrm{B}$ ratio was in the range of $4: 1: 2.5-5: 1: 4$. A talus cone deposit from another separate event was found standing between profiles 2 - 2' and 3 - 3'. This deposit did not lie over any existing talus deposit, and belonged to free-fall on the original slope. The deposition angles $\alpha, \beta$, and $\gamma$ of this talus cone are very close to $10-12^{\circ}$, the $\mathrm{W}: \mathrm{L}: \mathrm{B}$ was 3 $: 1: 1$.

(5) Profile 4-4': This locality was the highest one in the eastern cliff. Rocks exposed here were thick sandstone of the Shihti formation, differential erosion between thick-bedded sandstone and thin-bedded interbeds of sandstone and shale was not apparent. This location was judged to be where groundwater activities had the least effect on the recession rate, which for this location stood at $56.1 \mathrm{~m}$. A previous cliff line was situated proximal to the run-out area and the toes of the slope. At present, rock blocks mostly were comprised of free-fall rock

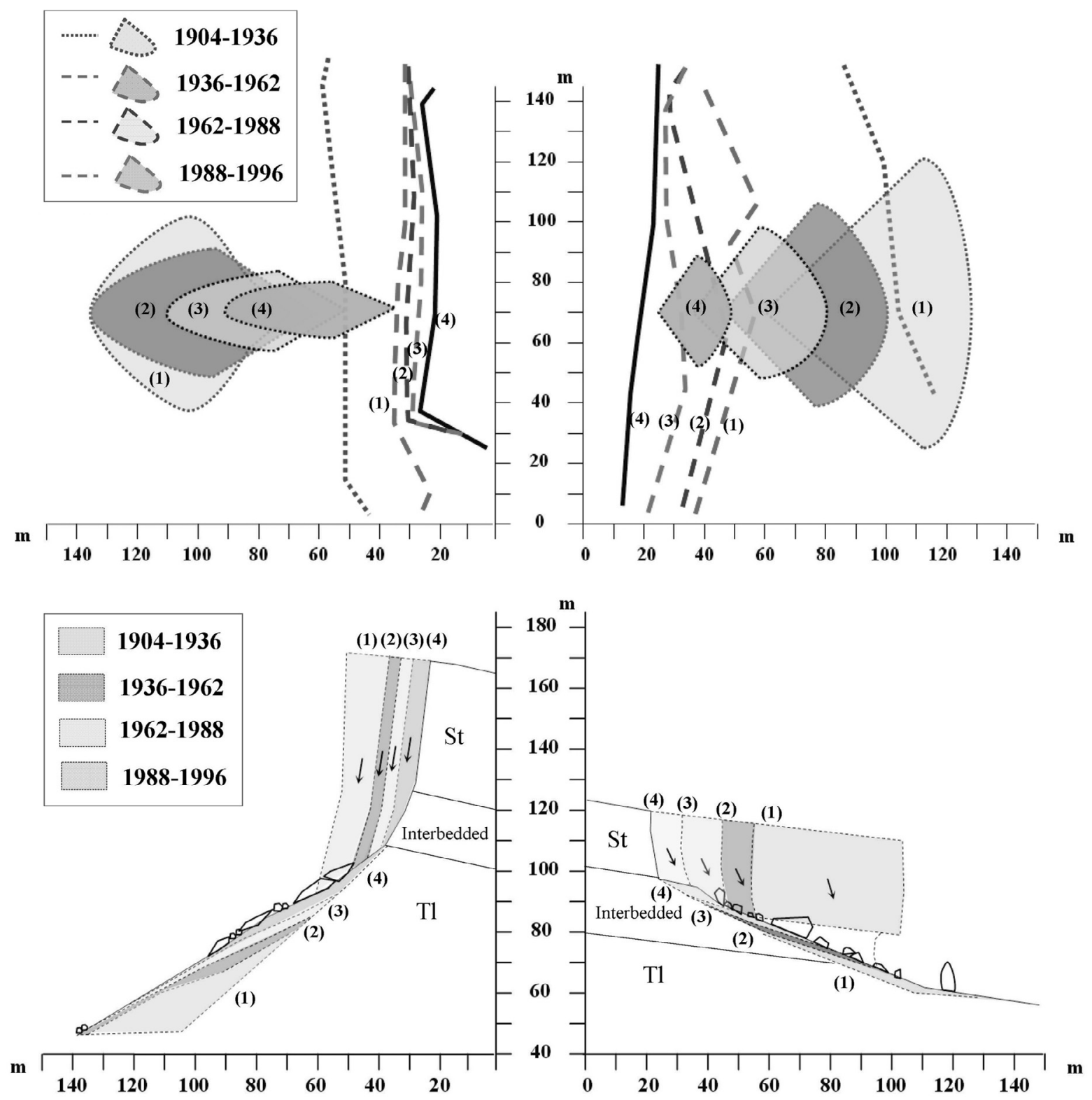

Fig. 10. An illustration of the relationship of cliff recession and talus deposits of typical profiles B - B' and D - D' at different time periods. 

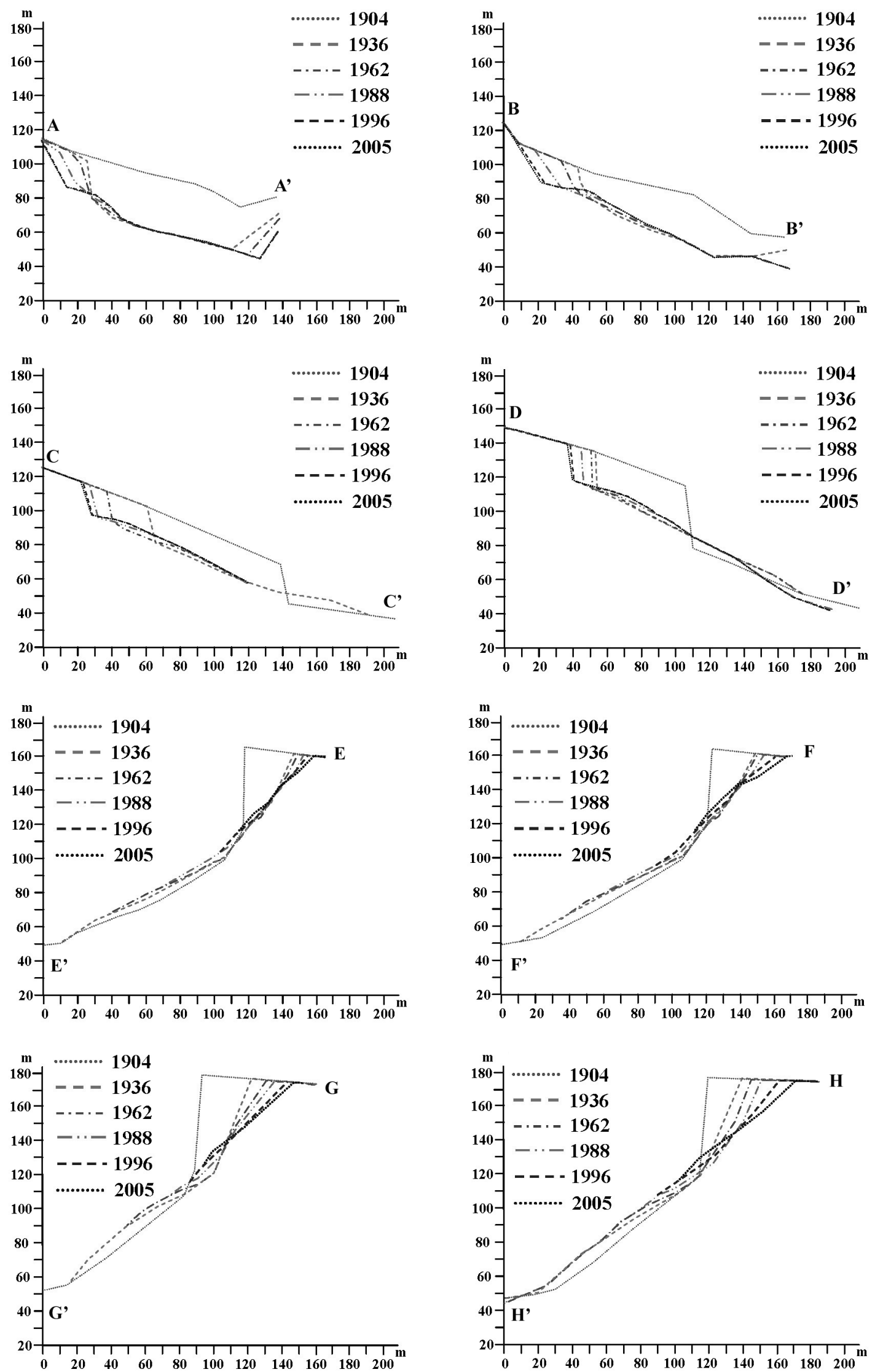

Fig. 11. The development of cliff recession and talus deposits at Xiangshan of 8 profiles (No. A - H). 
blocks detached due to joint controlled failure. Previously at the toes of this location there was a large deposit of talus, thus restricting and concentrating deposition of rockfall materials onto the upper slope of the existing talus deposit. Cliff recessions occurred in $1904-1936$, 1962 - 1988, and 1988 - 1996 periods. This deposit did not lie over any existing talus deposit, and belonged to free-fall on the original slope. The present talus deposit had gradually propagated to the deposit near the top of the cliff. A talus cone deposit from another separate event was also found standing between profiles $3-3$ ' and $4-4$ '. The $\mathrm{W}: \mathrm{L}: \mathrm{B}$ ratio was $6: 1: 2$; the upper slope inclined at $10-15^{\circ}$ and the lower slope $20-30^{\circ}$.

(6) Profiles 5-5' and 6-6': These two profiles are located in area of typical anaclinal setting. The elevation was higher than the eastern cliffs. Water erosion effects were minimal. Relative to other cliffs, the annual cliff recession rate was the smallest at $0.29-0.3 \mathrm{~m}$. Field investigation and geomorphic analysis revealed that large-scale cliff recession and deposition of talus materials occurred in the 1904 - 1938 period; in addition, in this period there were only sporadic occurrences of rockfall with a negligible cliff recession rate in this profile. In profile 6 - 6' large-scale rockfall events occurred in periods 1904 - 1936 and 1996 - 2005. The slope of movement in this profile was rather steep at $40-45^{\circ}$, thus resulting in deposits exhibiting $\mathrm{W}: \mathrm{L}: \mathrm{B}$ at $1: 1: 1$ and $1: 1.5: 1$ in appearance.

(7) Profiles 7 - 7' and 8- 8': These two profiles were located in a typical rockfall area in an anaclinal setting. The elevation was the highest in the Xiangshan area. Profiles $7-7^{\prime}$ and $8-8^{\prime}$ were located in highly active erosion gullies, thus the effects from both surface water and groundwater were quite apparent, thus resulting in the greatest cliff recession rate of $52-54 \mathrm{~m}$ in the western cliffs. Field investigation and geomorphic analysis indicated that in profile 7 - 7' 4 rockfall events occurred in the periods 1904 - 1936, 1936 - 1962, 1962 - 1988, and 1988 - 1996; in profile 8 - 8' there were 5 occurrences of rockfall for the periods 1904 - 1936, 1936 - 1962, 1962 - 1988, 1988 - 1996, and 1996 - 2005. The original run-out slope of $35-55^{\circ}$ and the number of deposition showed that the deposits were laid down in narrow, elongated forms, and, at $8-15 \mathrm{~m}$, were thicker than those in the eastern cliffs area. The deposits at these two profiles were mostly laid down on the surfaces of the slopes and developed and grew upward. The inclination of the upper slopes of these deposits were steeper at $30-35^{\circ}$, with gentler lower slopes at $25-30^{\circ}$, the $\mathrm{W}: \mathrm{L}: \mathrm{B}$ were $1: 0.8: 1-1: 1: 1.2$ in appearance.

(8) Based on the results from the present study described above, a scenario of cliff recession and progressive development of talus deposits at Xiangshan from 1904 to 2005 are proposed (Fig. 12). For the sake of convenience, they are described in forward sequence.

\section{DISCUSSION}

The difficulties and limitations that might be encountered in this study, namely, the field investigation, the geomorphic analysis, and the laboratory physical modeling test, were discussed as follows.

\subsection{Limitation of Field Investigation}

The initial deposition features of in-situ talus deposits may have changed a lot due to long-term environmental and human disturbances. The accuracy of the deposition features identified only from a field survey is at best limited. It is thus recommended that field investigation should be supplemented with interpretation of topographic maps and aerial photos at different periods. Aerial photos and topographic maps from different periods enable understanding the earlier cliff recessions and variations in deposition morphology. Such understanding would furnish information on the relation between cliff recession mechanisms and cliff recession rates.

Aerial photo study and field investigation revealed lush covers of vegetation on rock surfaces, lush vegetation growth were also present on both sides of tension cracks and gullies but had elevation anomalies, both of these two elevation anomalies could be recognised on aerial photo interpretation. Light cast on vegetation growing on different elevations would produce linear shadows. Granted that not all linear shadows are joint structures, the interpretation results in Fig. 5 was the result from in-situ investigation and comparison of topographic features. In the present study lineament interpretation was conducted through use of high precision LiDAR-derived $1 \mathrm{~m}$ DSM imageries, the accuracy was much enhanced.

The generally rough topography in rockfall areas and areas with ground surface cover presented great difficulties in field survey work. Use high resolution LiDAR DSM in identifying geomorphologic and geologic features is applicable except for areas with extremely abrupt topography and excessive ground surface cover. For example, we compared the spatial resolution of the $40 \mathrm{~m}$ DEM with the LiDAR-derived $1 \mathrm{~m}$ DSM within an area of $0.2 \mathrm{~km}^{2}$ within the study area. Within the comparison area are cliffs, talus deposits, joints, and erosion gullies. The $40 \mathrm{~m}$ DEM shows a 12 by 12 grid which fails to illustrate the terrain features (Fig. 13a). In contrast, the $1 \mathrm{~m}$ LiDAR DSM captures the variability of the ground which is essential for detailed surface (Fig. 13b).

\subsection{Limitation of Geomorphic Analysis}

The image data used in the study included the "Tai- 
wan Bau-Tu" maps (1904), the topographic maps (1936), the aerial photos (1962), the orthophotographic base maps (1988 and 1996), and the Taipei topographic maps (2005). However, since the image data involved various surveying and projection methods, error margins for these images might be greater than acceptable for research goals (Shen and Chang 2003).

Compared with the changes of cliff lines, the topographic relief of talus deposits was much larger so that the errors of measurement would be increased. Therefore, labo-
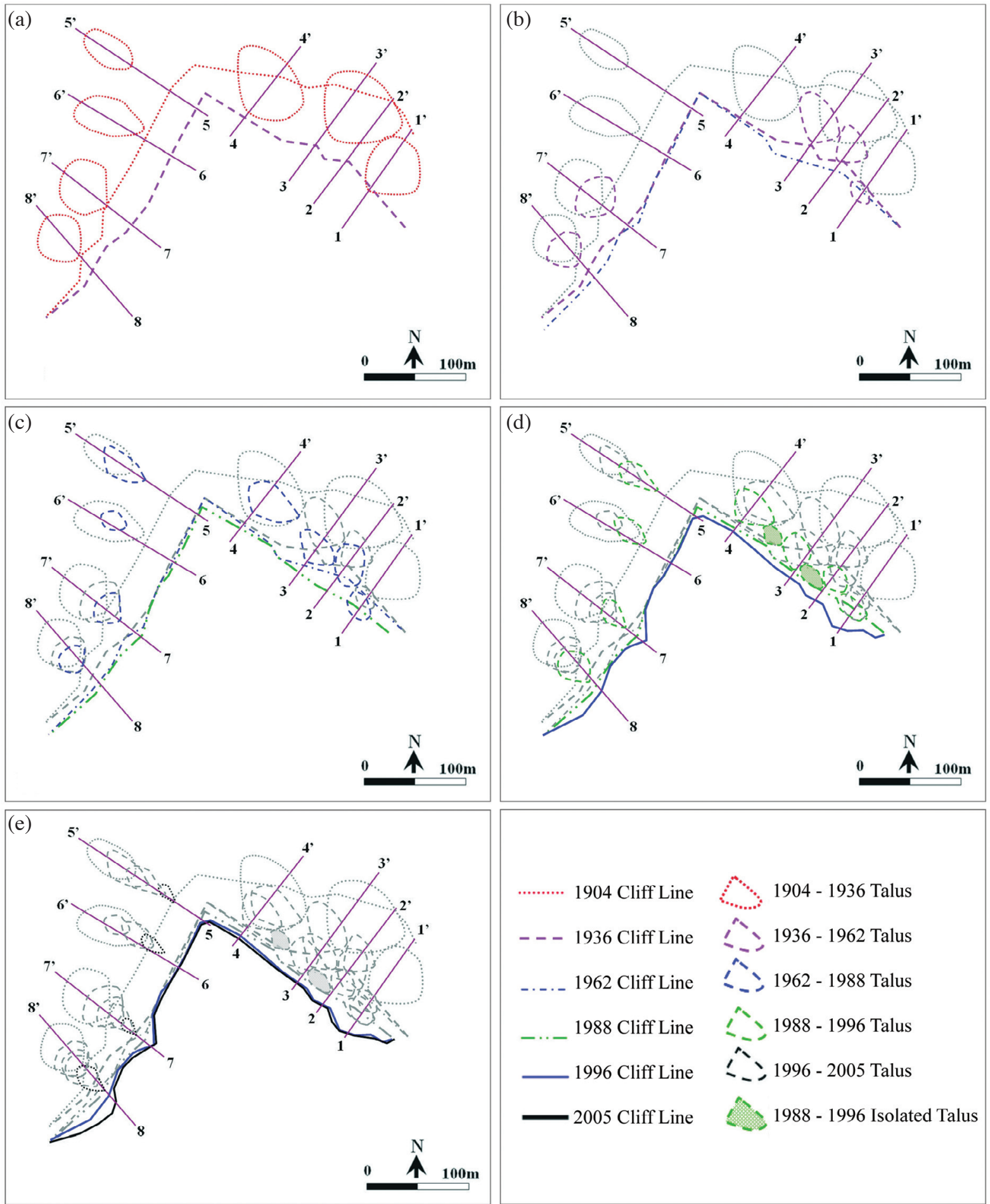

Fig. 12. The development process of cliff lines with talus deposits at Xiangshan at different time periods: (a) cliff retreat and talus deposits from 1904 - 1936; (b) cliff retreat and talus deposits from 1936 - 1962; (c) cliff retreat and talus deposits from 1962 - 1988; (d) cliff retreat and talus deposits from 1988-1996; and (e) cliff retreat and talus deposits from 1996 - 2005. 

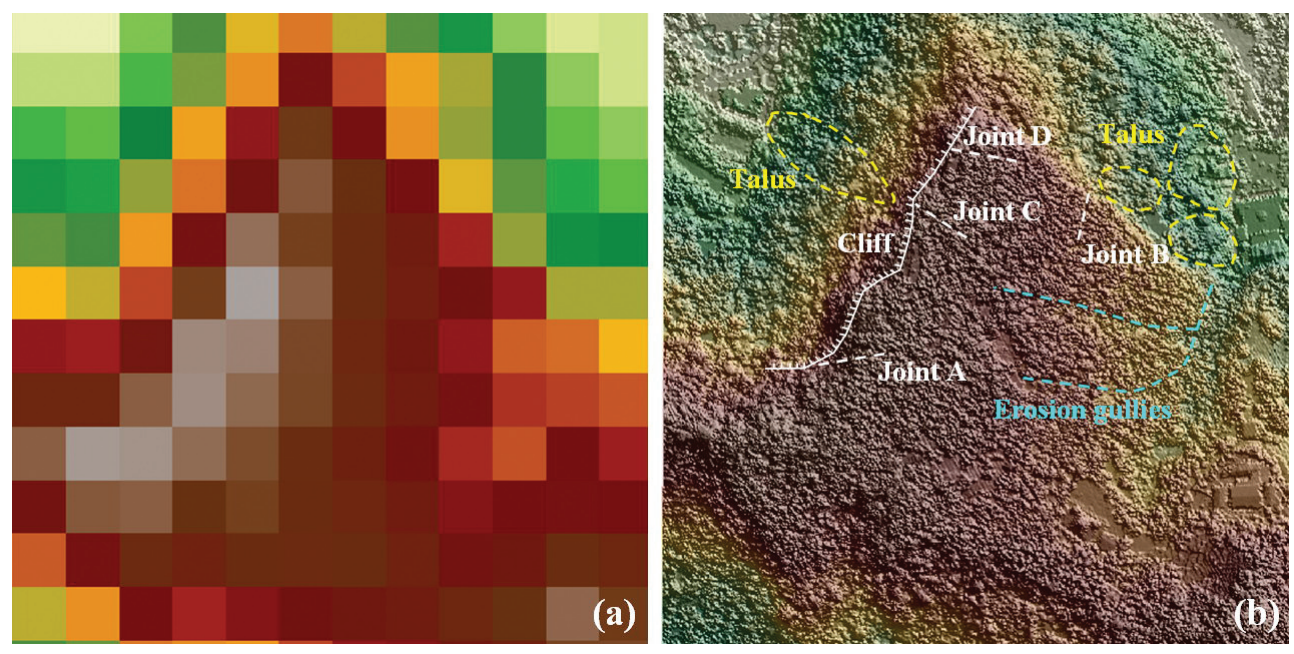

Fig. 13. Comparisons of $40 \mathrm{~m}$ DTM and $1 \mathrm{~m} \mathrm{LiDAR}$ DSM for a $0.2 \mathrm{~km}^{2}$ site within the study area. (a) $40 \mathrm{~m}$ DTM with color-coded elevation. (b) 1 m LiDAR DSM shown as color-coded shaded-relief image.

ratory physical modeling tests were conducted to acquire some insight to the talus development process in order to compensate for the lack of image interpretation results in the talus deposition areas. Thus, not only the precision of coordinates on topographic maps from various periods would be highly enhanced, but also the degree of error in cliff recession analysis for various periods would be estimated.

\subsection{Limitation of Physical Modeling}

Physical modeling tests were conducted to explore the relationship between the rock volume, original slope angle, fall type, and talus deposition pattern in this study. Due to the scaling effect problem, a small-scale model may differ from the actual rockfall behavior. Therefore, the qualitative analyses of physical modeling tests were conducted to establish the relation models in Xiangshan. Undeniably, a full-scale model would be the best method for analysis of rockfall movement and talus deposits but are far too costly and difficult to execute. In recent years, we witnessed an increase in innovative numerical approaches to the study of full-scale landslide simulation. However, to ensure that a numerical model could reveal reasonable predictions, the physical modeling tests and numerical analysis adopted must cross math with each other. The results of physical modeling were compared with those produced by numerical analysis so that the correctness of the numerical simulation could be justified. Subsequently, calibrated numerical methods adopted in the small-scale model were used to simulate the full-scale model. The simulation results should be as close to reality as much as possible. The application of full-scale numerical simulation will be a major topic in our future study; however, we will bear in mind the limitations of the use of numerical tools.

\section{CONCLUSION}

Based on field observations, five typical cliff recession profiles at Xiangshan are presented which are dominated by the orientation and spacing of the discontinuities, the influence of groundwater seepage, the thickness of interbeded layer crop out above the apex of the talus slope, and the degree of differential erosion. Data from 8 profile lines crossing perpendicular to the cliffs showed that the most severe recession occurred between 1904 and 1936 with a recession rate up to $2.13 \mathrm{~m} \mathrm{yr}^{-1}$ followed by that of $1.45 \mathrm{~m} \mathrm{yr}^{-1}$ between 1988 and 1996.

The geomorphologic changes of talus deposits in $\mathrm{Xi}$ angshan from 1904 to 2005 were also identified in the present study. The main talus deposition patterns in Xiangshan could be categorized into four types, i.e., (1) simultaneous cluster fall with gentle slope; (2) simultaneous cluster fall with steep slope; (3) Sequential sub-cluster fall with gentle slope; and (4) simultaneous cluster fall steep slope, which well correlate to the physical modeling tests $\mathrm{I}-30^{\circ}, \mathrm{I}-45^{\circ}$, II- $30^{\circ}, \mathrm{II}-45^{\circ}$. Since the initial topographic surface at eastern cliff was formed by gentle cataclinal slope, the talus deposits tended to spread wider, and appeared gently dipping in the upper and steep in the lower part. On the other hand, talus deposits below the western cliff were formed by steep anaclinal slope, they tended to deposit progressively backward towards the cliff line.

Acknowledgements The research is mainly supported by the National Science Council of Taiwan, Grant No. 96-2628-E-002-180-MY3. The advice, comments, and help provided by the editor and two anonymous reviewers have significantly strengthened the scientific soundness of this paper. Also, the authors thank Mr. Christopher Fong for his help to improve the paper. Their kind efforts are gratefully acknowledged. 


\section{REFERENCES}

Andriani, G. F. and N. Walsh, 2007: Rocky coast geomorphology and erosional processes: A case study along the Murgia coastline South of Bari, Apulia-SE Italy. Geomorphology, 87, 224-238, doi: 10.1016/j.geomor ph.2006.03.033. [Link]

Chan, Y. C., Y. G. Chen, T. Y. Shih, and C. Huang, 2007: Characterizing the Hsincheng active fault in northern Taiwan using airborne LiDAR data: Detailed geomorphic features and their structural implications. J. Asian Earth Sci., 31, 303-316, doi: 10.1016/j.jseaes.2006.07.029. [Link]

Curry, A. M. and C. J. Morris, 2004: Lateglacial and Holocene talus slope development and rockwall retreat on Mynydd Du, UK. Geomorphology, 58, 85-106, doi: 10.1016/S0169-555X(03)00226-5. [Link]

Drake, A. R. and P. J. Phipps, 2007: Cliff recession and behavior studies, Hunstanton, UK. Mar. Eng., 160, 3-17.

Hinchliffe, S. and C. K. Ballantyne, 1999: Talus accumulation and rockwall retreat, Trotternish, Isle of Skye, Scotland. Scott. Geogr. J., 115, 53-70, doi: 10.1080/ 00369229918737057. [Link]

Hutchinson, J. N., D. L. Millar, and N. H. Trewin, 2001: Coast erosion at a nuclear waste shaft, Dounreay, Scot- land. Q. J. Eng. Geol. Hydrogeol., 34, 245-268.

Obanawa, H. and Y. Matsukura, 2006: Mathematical modeling of talus development. Comput. Geosci., 32, 14611478, doi: 10.1016/j.cageo.2006.05.004. [Link]

Obanawa, H. and Y. Matsukura, 2008: Cliff retreat and talus development at the caldera wall of Mount St. Helens: Computer simulation using a mathematical model. Geomorphology, 97, 697-711, doi: 10.1016/j. geomorph.2007.09.013. [Link]

Pierre, G., 2006: Processes and rate of retreat of the clay and sandstone sea cliffs of the northern Boulonnais (France). Geomorphology, 73, 64-77, doi: 10.1016/j. geomorph.2005.07.002. [Link]

Pierre, G. and P. Lahousse, 2006: The role of groundwater in cliff instability: An example at Cape Blanc-Nez (Pas-de-Calais, France). Earth Surf. Proc. Land., 31, 31-45, doi: 10.1002/esp.1229. [Link]

Rocscience, 2002: Dips Version 5.1, Toronto, Ontario, Canada: 3-1-3-84.

Santos, Jr., O. F., R. F. Amaral, and A. C. Scudelari, 2004: Failure mechanisms of a coastal cliff in Rio Grande do Norte State, NE Brazil. J. Coast. Res., 39, 629-632.

Shen, S. M. and J. C. Chang, 2003: Application and limitation of the pictorial materials on the study of geomorphic changes in Taiwan. Geogr. Res., 38, 67-87. 